\title{
Growing Shrub Willow (Salix spp.) on Newly Reclaimed Minesoil in Northeastern West Virginia
}

\author{
Bartholomew Caterino
}

Follow this and additional works at: https://researchrepository.wvu.edu/etd

\section{Recommended Citation}

Caterino, Bartholomew, "Growing Shrub Willow (Salix spp.) on Newly Reclaimed Minesoil in Northeastern West Virginia" (2017). Graduate Theses, Dissertations, and Problem Reports. 5325.

https://researchrepository.wvu.edu/etd/5325

This Thesis is protected by copyright and/or related rights. It has been brought to you by the The Research Repository @ WVU with permission from the rights-holder(s). You are free to use this Thesis in any way that is permitted by the copyright and related rights legislation that applies to your use. For other uses you must obtain permission from the rights-holder(s) directly, unless additional rights are indicated by a Creative Commons license in the record and/ or on the work itself. This Thesis has been accepted for inclusion in WVU Graduate Theses, Dissertations, and Problem Reports collection by an authorized administrator of The Research Repository @ WVU. For more information, please contact researchrepository@mail.wvu.edu. 


\title{
Growing Shrub Willow (Salix spp.) on Newly Reclaimed Minesoil in Northeastern West Virginia
}

\author{
Bartholomew Caterino \\ Thesis submitted \\ to the Davis College of Agriculture, Natural Resources, and Design \\ at West Virginia University \\ in partial fulfillment of the requirements for the degree of \\ Master of Science in Forestry \\ Jamie Schuler, Ph.D., Chair \\ Shawn Grushecky, Ph.D. \\ Jeffrey Skousen, Ph.D. \\ Department of Forestry and Natural Resources
}

Morgantown, West Virginia

2017

Keywords: reclamation, revegetation, short rotation coppice, planting methods

Copyright 2017 Bartholomew C. Caterino 


\title{
ABSTRACT \\ Growing Shrub Willow (Salix spp.) on Newly Reclaimed Minesoil in Northeastern West Virginia
}

\author{
Bartholomew Caterino
}

Shrub willow (Salix spp.) has been a focus of international efforts to develop renewable alternatives for fossil fuels and to sequester carbon from earth's atmosphere. One area of interest has been to plant and cultivate willow on reclaimed mine lands. West Virginia's coalfields provide significant land area for incorporating willow cultivation into reclamation. The objective of this study was to develop silvicultural treatments to overcome the most common properties of mine soils in Appalachia: high rock fragment content that often causes difficult planting, reduced nutrient availability, and low water-holding capacity. Cuttings of three shrub willow clones were planted with six planting/fertilizer treatments. The planting treatments compared a horizontal planting method that was more efficient than digging full depth holes into compacted and rocky mine soils to traditional vertical planting of cuttings. Fertilizer treatments compared no fertilization to controlled release and traditional fertilizer at a rate of $140 \mathrm{~kg} \mathrm{~N} \mathrm{ha}^{-1}$. Following two growing seasons, clones clearly differed in survival and production but the influence of fertilizer treatments was inconsistent Survival and growth were lower for horizontally-planted cuttings relative to vertically planted cuttings. Response to fertilizer varied by clone. Results of this study will be used to direct future establishment practices for willow on reclaimed mine soils in West Virginia. 


\section{TABLE OF CONTENTS}

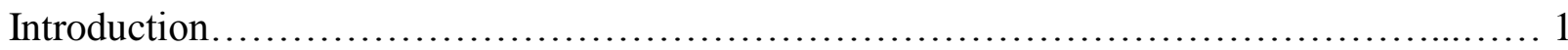

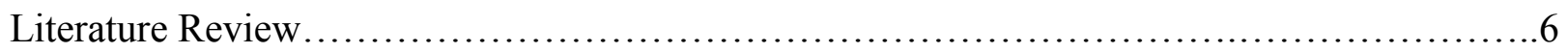

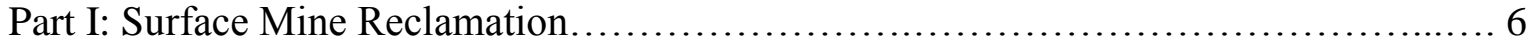

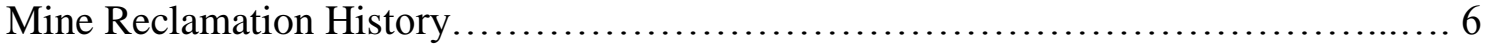

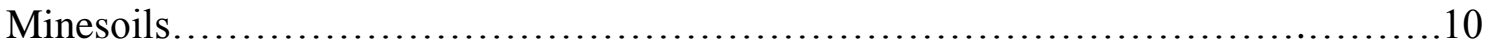

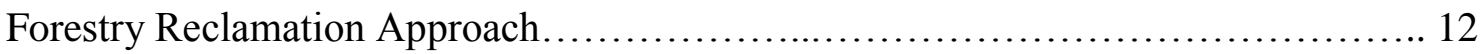

Willow Suitability for Reclamation........................................... 14

Part II: Willow Cultivation............................................................ 17

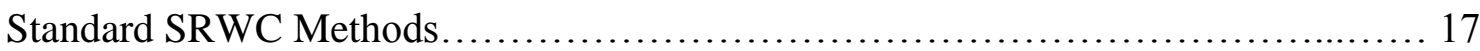

Alternative Planting Methods......................................................... 19

Improved Willow Breeding.................................................... 21

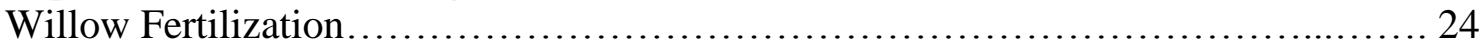

Carbon Allocation Patterns...................................................... 25

Predicted Experimental Outcomes...............................................26

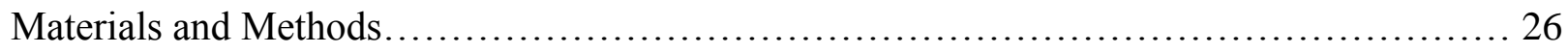

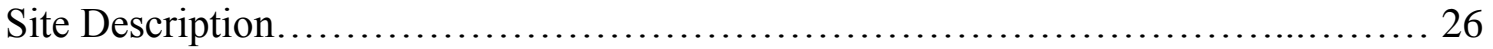

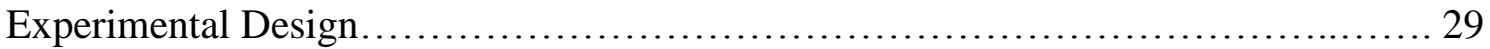

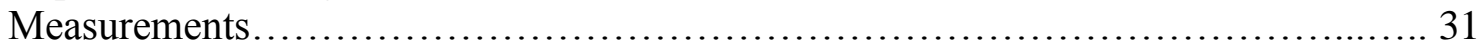

Statistical Analyses................................................................. 31

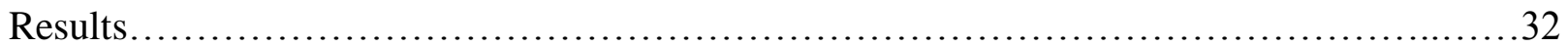

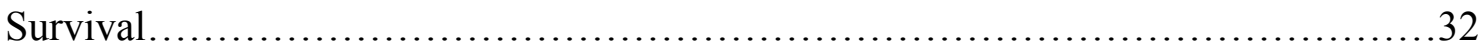

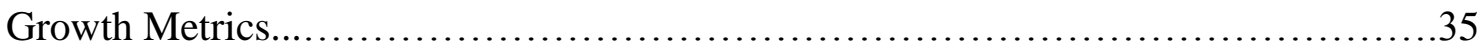

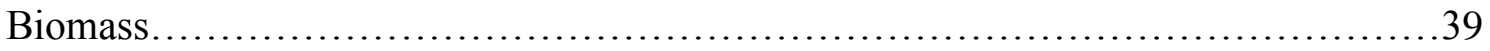

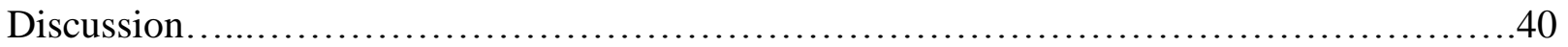

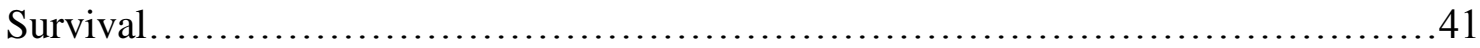

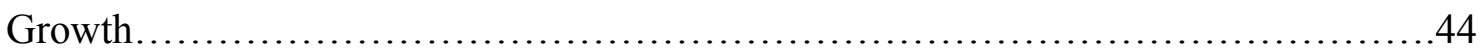

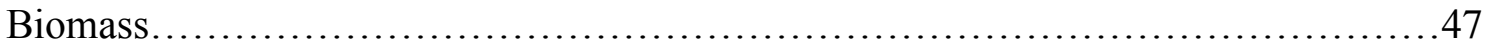

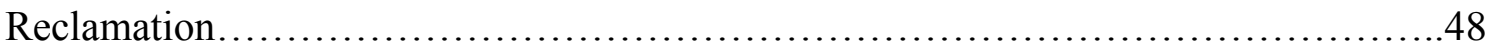

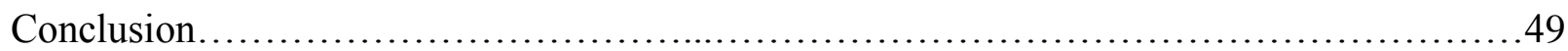

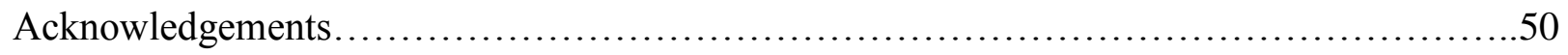

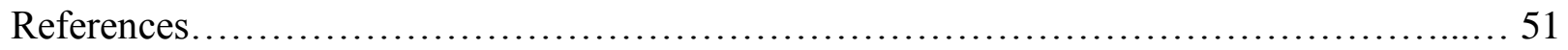




\section{INTRODUCTION}

The practice of cultivating woody plant species in short rotation has become more prominent as a method to produce large quantities of biomass to feed the growing bio-energy sector. Woody biomass grown in short rotation woody crop (SRWC) plantations has produced superior energy output compared to sugar and starch crops used for bio-fuel production, namely, corn, wheat, sugar cane and sugar beet (Cherubini, 2010). The net energy realized from woody biomass has been measured at 16 times greater than the energy required for production and processing compared to 1.3 times for sugar and starch crops (Volk et al., 2006). Much of the energy advantage has been attributed to the low-input requirements of SRWC systems. Woody crops are perennial and require only initial competing vegetation control, fertilization and periodic harvesting. Species like shrub willow (Salix spp.) can sustain up to seven three-year harvest cycles during an approximate twenty-two year rotation. Contrastingly, agricultural crops require annual tillage, planting, fertilization, and pesticides. The inherent input-advantages of SRWC systems translate to reduced carbon emissions, lessened production costs and greater energy outputs (Keoleian and Volk, 2005).

The composition of woody plant material offers further advantage over starch and sugar crops for flexible and efficient utilization. Starch and sugar crops are harvested for their seed or grain, and stover which render polysaccharide sugars $\left(\mathrm{C}_{6} \mathrm{H}_{10} \mathrm{O}_{5}\right)$ that are easily fermented into ethanol. Only a small portion of the plant biomass is converted to bio-energy. Woody biomass is composed of cellulose $\left(\left(\mathrm{C}_{6} \mathrm{H}_{10} \mathrm{O}_{6}\right)_{n}\right)$, hemicellulose $\left(\left(\mathrm{C}_{5} \mathrm{H}_{8} \mathrm{O}_{5}\right)_{n}\right)$, and lignin $\left(\mathrm{C}_{9} \mathrm{H}_{10} \mathrm{O}_{2}\left(\mathrm{OCH}_{3}\right)_{n}\right)$ which may be partitioned and processed into several products including fiber, liquid fuels, and chemicals (Cherubini, 2010). The entire branch structure of woody crops is harvested for useable 
fiber. Of the most expedient and flexible applications for woody biomass are direct biomass firing or co-firing in existing coal burners for electricity production.

In co-firing applications, willow combustion reduces $\mathrm{SO}_{2}$ emission, and $\mathrm{NO}_{\mathrm{x}}$ greenhouse gas emissions (Keoleian and Volk, 2005). At $10 \%$ willow co-fire, $\mathrm{NO}_{\mathrm{x}}$ emission, $\mathrm{SO}_{2}$ emissions and $\mathrm{CO}_{2}$ emissions can reduce by $5.2 \%, 9.5 \%$ and $9.9 \%$, respectively compared to traditional coal firing. While $100 \%$ bio-firing can reduce $\mathrm{CO}_{2}, \mathrm{SO}_{2}$ and $\mathrm{NO}_{\mathrm{x}}$ emissions by $70-98 \%$ in (Keoleian and Volk, 2005).

The expansion of co-firing for energy production will require large expanses of acreage. Keoleian and Volk (2005) have documented the need for 2925 hectares of shrub willow to supply a 100 megawatt (MW) steam boiler in Dunkirk, NY at 10\% co-fire. Other utilization studies estimated that 325 ha of willow crop are required for each $1 \mathrm{MW}$ of electricity produced through co-firing. Such a scenario assumes willow production at approximately $17 \mathrm{Mg} \mathrm{ha}^{-1} \mathrm{yr}^{-1}$ (Volk et al., 2006).

Acquiring the land resource for woody biomass crops is not necessarily a limiting factor. These crops can be cultivated on marginal lands that are not suitable for agricultural production (Keoleian and Volk, 2005). Mosseler et al. (2014a) have cited the potential of willow to revegetate highly disturbed mine sites composed of crushed shale overburden in New Brunswick, Canada. Trials in Poland by Stolarski et al. (2014) have similarly suggested that willow crops, grown on poor quality soils (a brunic arenosol developed from loose sand with $41 \mathrm{~cm}$ depth to native rock) may provide sufficient yield for commercial implementation, approximately $9 \mathrm{Mg}$ $\mathrm{ha}^{-1} \mathrm{yr}^{-1}$.

In the United States, the continual development of shrub willow (Salix spp.) in SRWC systems has served as a model for expanding biomass production to reclaimed lands. Willow 
research began in the United States in 1986 (Smart and Cameron, 2008). Research has included yield trials, breeding programs, cultural practices, and site trials. Biomass utilization research has included harvesting systems, feedstock properties and firing trials. On agricultural soils and on sub-prime agricultural sites, researchers and growers have observed dry yields exceeding 8-12 $\mathrm{Mg} \mathrm{ha}^{-1} \mathrm{yr}^{-1}$ (Volk et al., 2016). A localized commercial willow market has developed in places like Black River, NY and Lyonsdale, NY where $60 \mathrm{MW}$ and 40MW biomass firing facilities, respectively, produce combined heat and power (CHP) (Volk et al., 2016). The facilities fire willow from eleven local growers in addition to forestry residues for power production. The New York facilities were implemented by a partnership between ReEnergy, LLC and the State University of New York (SUNY). Similar research specific to minesoils and partnerships between researchers and energy producers are the keys to developing woody biomass plantations on reclamation sites in Appalachia.

West Virginia's coal fields contain over 22,500 hectares of surface mined land available for biomass plantation development. These were categorized as barren land and mines reclaimed to grass land with slopes lesser than 10\% (Maxwell et al., 2012). State legislation throughout the 2000s reinforced the importance of forestry as a post-mining land use. Reforestation returns the land to its pre-mining use and is the practical land use for mines in areas that are remote to human development and surrounded by natural timber land (WVDEP, 2011). Within the surface mining rules, allowances have been made for plantations of bio-energy crops as a means to achieve reclamation bond release.

Cultivation of woody crops for biomass energy has offered mine operators an alternate means to achieve bond release and the potential to produce a salable commodity for the energy industry. The goal of this research was to investigate methods to implement commercial scale 
biomass plantations on surface minesoils. The potential woody biomass system would capitalize on the prevalence of coal burning power plants in West Virginia, and throughout Appalachia, that are within $80 \mathrm{~km}$ to mine reclamation sites (Abrahamson et al., 1997). Coal-burning power plants would co-fire willow biomass with coal in order to reduce the amount of coal burned and to reduce $\mathrm{CO}_{2}, \mathrm{NO}_{\mathrm{x}}$ and $\mathrm{SO}_{2}$ emissions (Keoleian and Volk, 2005). Emissions reductions associated with co-firing willow have been closely tied to the fuel burned in feedstock transport. Close proximity of harvest site to end-user would maintain the carbon benefit of biomass firing and create a localized biomass market as was developed in New York State.

Growing high-yielding biomass crops on mined land is the first hurdle for developing a biomass market in West Virginia. The known problems with establishing woody vegetation on reclaimed soils have been extensively documented in the Forestry Reclamation Advisories published by the Appalachian Regional Reforestation Initiative (ARRI). The problems have been traced back to the requirements of the Surface Mining Control and Reclamation Act (SMCRA) of 1977. The act required that soils be mechanically stable and revegetated, but did not require reforestation. Commonly, soils underwent optimal engineering compaction to the surface and were seeded with perennial grasses for pasture creation. Those practices fulfilled the reclamation requirements but did not create soil conditions conducive to forest establishment.

The ARRI guidelines sought to direct reclamation practices toward more careful preparation of topsoil material. Stockpiling the native topsoil and upper weathered rock layers was recommended to aid in preparation of reclamation soils. Desirable soils exhibited pH between 5 and 7 (Burger et al., 2009). A loosely graded rooting medium of four foot (1.2 m) depth was imperative. Liming to control acidity and fertilization were standard recommendations to improve nutrient status. Slower growing cover- grasses, i.e. orchardgrass (Dactylis glomerata 
L.), perennial rye (Lolium perenne L.), and red top (Agrostis gigantean), were recommended for tree establishment. On sites that met ARRI recommendations, hardwood seedlings exhibited 7080\% survival (Davis et al., 2010).

Even with improved reclamation techniques for hardwood establishment, soil conditions on some mines remained outside of the ideals for willow plantations. Willows were most successful on agricultural soils of moderate acidity ( $\mathrm{pH}$ 5.5-6.5), loamy soil, coarse to fine grained structure, and soils that were imperfectly to moderately well drain (Abrahamson et al., 2010). Contrastingly, mine soils exhibited bulk density greater than $1.05 \mathrm{Mg} / \mathrm{m}^{3}$ (forest soils), had coarse, rocky texture, and minimal fines content (DeLong and Skousen, 2012). High acidity $(\mathrm{pH}<5.0)$ and low organic matter content were also characteristic of new mine soils (Thomas et al., 2015). Competition from any vegetation has been shown detrimental to willow establishment as willows compete from the ground level whereas timber species compete from the established seedling height (Albertsson et al., 2014). This suggests that reclamation grasses may impede willow survival.

Theoretically, willow could survive and grow well on sites prepared in accordance with the Forestry Reclamation Advisories. Willows in particular have proven valuable as pioneer species, establishing on sites, with sub-optimal soil conditions, and growing rapidly once established on industrial spoils, mine and gravel pits, peatlands, overburdens, quarries and highly eroded soils (Kuzovkina and Volk, 2009). However, the goal for mine reclamation plantations for energy would be to achieve commercial biomass dry yields greater than $6 \mathrm{Mg} \mathrm{ha}^{-1} \mathrm{yr}^{-1}$ (Keoleian and Volk, 2005). Mosseler et al. (2014a) recorded fresh willow yields on mine soils at 4.2 $\mathrm{Mg} \mathrm{ha}^{-1}$. Dry yield of that harvest would have been far below economic viability. 
The productivity shortfalls in mine reclamation willow plantations have prompted continued research towards obtaining viable willow yields on mine soils. The research that follows aimed to test silvicultural treatments to overcome the high rock fragment content (that often causes difficult planting) and the reduced nutrient status of surface mine soils. The experiment explored the growth patterns of three popular willow clones established under various fertilization regimes and planting techniques. The specific objectives of the experiment were as follows:

- Compare the survival of three willow clones on high altitude, surface mine soils in order to determine their suitability for cultivation on sandstone-derived minesoils.

- Assess the efficacy of an alternative horizontal planting method to overcome difficulty planting cuttings on sites with high soil rock fragment content.

- Compare the growth and biomass of willow clones under improved fertility treatments using traditional inorganic fertilizer and time-release fertilizer formulations.

- Compare the patterns of aboveground biomass allocation to shoots and leaves associated with the various combinations of willow clone and fertility treatments.

\section{LITERATURE REVIEW}

\section{Part I: Surface Mine Reclamation}

\section{Mine Reclamation History}

The coal surface mining boom in the United States began in the 1930s and continued through WWII. Demand for coal to fuel wartime production was high. A downtick in domestic construction projects at that time left construction equipment idle and available to mine coal from the surface near outcrops (Potter et al., 1951). Operators found surface mining an efficient means to access shallow coal seams that would otherwise be too thin for investment in an 
underground operation. Early surface operations were small in cross section. High walls were at most 10 meters and the largest benches were several hundred feet wide. The most considerable dimension could be the length, where mines may wind several miles along a contour. Without reclamation, the landforms left by these early surface mines were bare benches, overburden dumps and high walls. Potter et al (1951) cited land erosion and spoil dump instability as the main problems with early surface mines. Rains caused siltation of drainages and sliding of soil material that was hazardous to infrastructure and persons below the strip. These early mined sites were slow to revegetate due to soil movement, poor soil fertility, and adverse chemical properties.

By 1939, legislators in West Virginia recognized the hazards of abandoned strip mines and passed regulations requiring surface mine reclamation. The first bonding system was set up in 1945. The laws required a bond of $\$ 500$ per acre (a minimum bond of $\$ 1000$ was required) to insure re-grading of land, correcting off-site drainage problems, and re-vegetating the site. In practice, these laws commonly amounted to operators replacing soil on the site and performing minimal grading. While these actions may seem counter to bond requirements, Potter et al. (1951) reported that minimally graded sites were occupied by four times greater vegetation than sites that were completely graded. Ungraded, rough soil replacement created conditions for wind-blown seed entrapment from adjacent forest. The loose soils created a seedbed that held water and facilitated germination. Contrastingly, hard graded sites were subject to high run-off flows that caused soil erosion and soil mass instability. The compacted soils and soil movement were not conducive to water holding or root propagation.

Following WWII, strip mining operations disturbed larger land areas. Earthmoving equipment had become larger to more efficiently move large volumes of rock overburden. 
Operators were excavating to greater depths and exposing overburden beyond the weathering zone, approximately $10 \mathrm{~m}$ (Zipper et al., 2011b). The "upside down" method of stripping was prevalent (Gorman et al., 2001). Topsoil and sub-soil materials were cast off first and unweathered overburden was placed at the surface. This method resulted in coarse, acidic soils at the surface that were hostile growth mediums for colonizing and planted trees. Ten percent tree survival was common (Gorman et al., 2001). Reclamation regulations at the time were insufficient to remediate land affected by more modern large-scale surface mining.

As time progressed, environmental problems associated with coal mining came to the legislative front in the United States. In 1972, the Clean Water Act (CWA) began regulating industrial discharges into public water ways. In order to achieve compliance, surface mine sites needed to mitigate erosion, sedimentation, and acidic drainage from uncontrolled placement of mine spoils. The Surface Mining Control and Reclamation Act (SMCRA) of 1977 was passed to further CWA compliance and to reduce slope failure hazards. Early reclamation operations under SMCRA focused on returning the land to the approximate original contour (AOC) and burying hazardous spoil material. Spoils underwent optimal mechanical compaction for slope stability (Zipper et al., 2011b). Seeding of herbaceous vegetation was emphasized to control soil erosion.

The basic tenet of the SMCRA was to restore the land to a condition capable of supporting the pre-mining land use or re-purposing the land for a higher and better use (Skousen and Zipper, 2014). Higher uses were ranked based on economic significance, land value, and surrounding land uses. In this fashion, industrial or residential development was valued over farm/pasture use, which was valued over forestry use. However, much of the surface mined land in West Virginia was remote to population centers and hay/pasture or forestry were the most practical permitted land use. The majority of mines reclaimed in the 1980s and 1990s were 
permitted to hayland and pasture which easily fulfilled requirements for erosion, sedimentation and revegetation during the early implementation of SMCRA (Skousen and Zipper, 2014). Subsequently, native trees eventually colonized some fallow sites as seeds became established from adjacent forest lands. On most sites, however, dense herbaceous vegetation arrested succession of natural forest species.

Reclamationists and legislators in West Virginia have recognized the incompatibility of grassland restoration within the Appalachian landscape. The current state surface mining reclamation rule requires land disturbed by surface mining to be restored to conditions capable of its pre-mining use that is compatible with surrounding undisturbed land (WVDEP, 2011). On mines permitted to AOC reclamation, commercial forestry and forestry are often the default option in undeveloped regions of the state. Reclamation rules further prohibit a change of the originally permitted post-mining land use from forestry to hayland or pasture as forest land constitutes higher land capability. In support of forestry land uses, the reclamation rule has specified soil placement procedures, acceptable ground cover vegetation, and native Appalachian tree species for reclamation. Among the recommended species are white oak (Quercus alba), chestnut oak (Q. montana), northern $\operatorname{red}$ oak (Q. rubra), black oak (Q. velutina), white ash (Fraxinus americana), yellow-poplar (Liriodendron tulipifera), basswood (Tilia americana), cucumber magnolia (Magnolia acuminata), black walnut (Juglans nigra), sugar maple (Acer saccharum), black cherry (Prunus serotina), or native hickories (Carya spp.). Implementing the required reforestation on surface mines caused practices to shift, and continually progress toward building minesoils that facilitate the growth of commercial Appalachian tree species. 


\section{Minesoils}

The provisions of the SMRCA required operators to build minesoil for revegetation rather than simply restore the contour with rock overburden. This required some pre-mining subsurface investigation for available topsoil thickness, soil horizons and extent of weathered R horizon material (Skousen et al., 2011). Where topsoil was less than $15 \mathrm{~cm}$ in thickness, as is the case for many Appalachian surface mines, a mixture with weathered rock material ( $\mathrm{R}$ horizon) is admissible during reclamation (Emerson et al., 2009). It is recommended that operators salvage soils of the O, A, E, B, C and R horizons (Skousen et al., 2011). Native topsoils are the most desirable materials for forestry reclamation because they include the $\mathrm{O}$ horizon, the forest seed bank, and soil microorganisms. Operators should replace topsoil materials immediately following removal (e.g. on adjacent pit areas during continuous reclamation) because propagules and microorganisms lose viability shortly after stockpiling. Should operations dictate stockpiling, native topsoil has value as source of organic matter and finer textured material for creating the most suitable revegetation medium. At the culmination of reclamation, soils are required to be of suitable thickness and distribution such that they facilitate the permitted post-mining land use, restore the site to $\mathrm{AOC}$, and create the required drainage.

Often, to achieve adequate topsoil depth, operators must utilize topsoil substitutes. The available substitute materials include sandstones, siltstones, and shales that are interbedded with coal in the central Appalachian region. As a result, Appalachian minesoils often have greater than $50 \%$ rock fragment content (Johnson and Skousen, 1995). These rock materials may be weathered or un-weathered based on depth of origin during mining. When exposed to atmospheric conditions, each rock type weathers and decomposes differently. Subsequently, the minesoil takes on different properties based on its parent rock composition. 
Sandstones weather and decompose to form soil with a sandy loam texture that is more similar to Appalachian forest soil than soil derived from other parent rocks (Zipper et al., 2011a). However, sandstones must be distinguished between weathered "brown" sandstone and unweathered "gray" sandstone. Brown sandstone decomposes more readily because it originates closer to surface soils, under the influence of oxidation from surface moisture and air. Gray sandstones are structurally stronger and weather more slowly because they originate deeper in the geologic column, beyond the zone of surface influence. Emerson et al. (2009) measured silt and clay content in brown sandstone and gray sandstone at $61 \%$ and $34 \%$, respectively, which was indicative of slow weathering of the gray material. Siltstone and shale materials decompose to soils having heavier clayey texture. These soils have been suggested to restrict water percolation and air movement in the rooting zone.

Chemical properties further influence minesoil performance for reforestation. Brown sandstone materials have acidity in the range of Appalachian forest soils, $\mathrm{pH} 4.5$ to 6.0 (Skousen et al., 2011). Materials composed of gray sandstone, siltstone, and shale are more alkaline with $\mathrm{pH}$ between 6.5 and 8.5. Soluble salt content, measured as electrical conductivity (EC), is more compatible with forest trees in brown sandstone, with EC generally $<0.4 \mathrm{ds} \mathrm{m}^{-1}$ (Skousen et al., 2011). Rodrigue and Burger (2004) catalogued several studies that measured EC in silt, shale and gray sandstone mine soils between 0.3 and $3.0 \mathrm{ds} \mathrm{m}^{-1}$. Those EC conditions impeded tree survival. Minesoils composed of gray sandstone, siltstone and shale generally contain higher levels of the essential plant nutrients $\mathrm{Ca}, \mathrm{Mg}, \mathrm{K}$, and $\mathrm{S}$ which contribute to base saturation and enhance tree growth as soils weather (Rodrigue and Burger, 2004).

In practice, researchers have observed similar survival rates of Appalachian hardwoods, greater than $70 \%$ on both brown sandstone and gray sandstone soils (Skousen et al., 2011). 
However, tree growth has been the distinguishing factor. Emerson et al. (2009) observed five times greater tree volume growth on weathered brown sandstone versus gray sandstone after three years. Similarly, Angel et al. (2008) found that brown sandstone minesoil supported twice the volume of yellow-poplar (Lirodendron tulipifera) and thirty times the cover of volunteer vegetation compared to gray minesoil. It has become the consensus that brown sandstone minesoils, due to finer texture and closer chemical properties to natural soils, are a superior topsoil substitute for forestry reclamation. However, material differences, such as pyrite content (high sulfur), are site specific, and other materials should be substituted if brown spoils are deemed chemically unsuitable.

Selection of the best possible materials, as previously discussed, is the basis of constructing productive minesoils. Johnson and Skousen (1995) suggested that the physical texture of minesoils is far more difficult to correct than chemical deficiencies. Soil acidity can be controlled with lime application. Fertility can be enhanced with fertilizer application and organic matter amendments. But there remains little substitute for creating a minesoil composed of native topsoil and/or weathered sandstone spoil and placing un-compacted materials to facilitate forest growth.

\section{Forestry Reclamation Approach}

A significant impediment to tree establishment has been caused by soil compaction and seeding with perennial herbaceous vegetation on surface mines reclaimed to pasture. The compaction performed by leveling operations on reclaimed sites was suggested as the greatest impediment to hardwood survival by Burger et al. (2002). Similarly, Andrews et al. (1998) found that compacted c-horizon soils arrested root growth in eastern white pine (Pinus strobus) on areas that were not ripped before planting. The increased density of compacted mine soils caused 
poor percolation and perched water which translated to insufficient plant available water and impeded white pine survival.

Seeded grass vegetation on post-SMCRA sites exacerbates the effects of soil compaction by providing competition for already limited growth resources. King and Skousen (2003) found that hardwood survival was significantly greater in areas where vegetation was controlled to less than $50 \%$ ground cover.

In response to the documented reforestation failures, and armed with methodologies from successful reforestation efforts, the ARRI began publishing its Forestry Reclamation Advisories in 2005. The key components of the method were outlined in the Forestry Reclamation Approach (FRA) (Burger et al., 2005):

1. Create a suitable rooting medium for good tree growth that is no less than $1.2 \mathrm{~m}$ deep and comprised of topsoil, weathered sandstone and/or the best materials feasible.

2. Loosely grade the topsoil or topsoil substitute established in step one to create a noncompacted growth medium.

3. Use ground covers that are compatible with growing trees.

4. Plant early successional trees for wildlife and soil stability, and commercially valuable trees.

5. Use proper tree planting techniques.

Creating a suitable rooting medium was a two-part process, best accomplished by planning the topsoil material prior to mining. Stockpiling the native topsoil, if feasible, and the surface layers of weathered rock material was recommended to provide topsoil that was close to the loamy texture of native soils. Utilizing only surface materials further ensured the best possible chemical properties to achieve acidity within the tolerances of Appalachian hardwoods, 
(pH 5.5-6.5). Materials from deeper rock layers were compacted using standard engineering methods within $1.2 \mathrm{~m}$ of the final elevation. Topsoil was placed by end dumping, or by one-pass grading to final elevation. The aim of end dumping or loose grading was to reduce soil bulk density, creating a growth medium in which seedlings were easily planted, roots could propagate and water could infiltrate (Sweigard et al., 2007).

Improved growth medium for trees, however, was also improved growth medium for reclamation grasses. Grass cover could not be eliminated because of ground cover requirements for erosion control. Alternatively, Burger et al. (2009) recommended slower growing cover species including perennial ryegrass (Lolium perenne ssp. perenne), annual ryegrass (Lolium perenne ssp. multiflora), and birdsfoot trefoil (Lotus corniculatus). These species have shorter stature than traditional reclamation grasses (e.g. tall fescue (Lolium arundinaceum)) and uptake water at a lesser rate to reduce competition with seedlings for light and resources.

The FRA encouraged soil amendments to control acidity and improve nutrient status. Soils with $\mathrm{pH}$ below 5.0 were recommended for liming at the appropriate rate to correct acidity into the range for hardwoods. Fertilization with N, P, K fertilizer was encouraged for all mine soils. However, lesser rates of $\mathrm{N}\left(56-79 \mathrm{~kg} \mathrm{ha}^{-1}\right)$ than phosphorous $\left(90-112 \mathrm{~kg} \mathrm{ha}^{-1}\right)$ were recommended to discourage rapid grass growth in the first year and feed tree growth with phosphorous beyond the establishment year.

\section{Willow Suitability for Reclamation}

Salix have been cited as early colonizers of disturbed soils (Kuzovkina et al., 2004). They exhibit the most common traits of early successional species — shade intolerance and relative fast shoot growth. Natural willow colonization has been observed on characteristically nutrientpoor soils such as those comprising sand dunes, bogs and gravel bars in riparian areas. These 
sites are open habitats that are subject to frequent disturbance from erosion and deposition. Anthropogenically disturbed sites including industrial spoils, gravel pits, mined lands, and quarries represent analogous environments which willow may colonize (Kuzovkina and Volk, 2009).

Willow propagate by wind-blown seed and by vegetative propagation, both of which aid the ability to colonize disturbed sites. To facilitate vegetative propagation, each node on a willow stem contains root primordia (Kuzovkina and Volk, 2009). The root primordia exploit any soil contact and develop into root apical meristems within 48 hours (Fjell, 1985). In natural propagation, broken live stems will root where deposited. For plantation establishment, willow can be easily planted from stem cuttings. Willow twigs that deposit naturally, or are planted in the horizontal position, rather than buried vertically in the soil, will root and produce shoots (McCracken et al., 2010). Once rooted, willow have exhibited dense root systems that have high tensile strength and downward propagation to access groundwater (Kuzovkina and Volk, 2009). These rooting habits have allowed willows to survive root exposure from soil erosion and stand firm against high water flows in riparian settings. Willow have also survived soil deposition in erosive environments.

Willow survival on upland sites has been attributed to the efficient resource utilization observed in some willow species. For example, Svortskov (1999) reported species such as Salix reticula that inhabited rock slopes and taluses with fair to moderate moisture conditions. The Salix genus contains over 450 species including 125 in the Vetrix subgenus that are utilized for biomass plantations (Keoleian and Volk, 2005). Diverse genetics and a wide native range have made possible the selection of Salix species that match climactic conditions on targeted plantation sites (Kuzovkina and Volk, 2009). Breeding programs have selected genotypes that 
yielded the greatest aboveground biomass and tolerated high planting densities. Genotypes have also been bred for drought tolerance, low nutrient requirements, tolerance of salinity, and tolerance of high or low soil pH (Kuzovkina and Volk, 2009). Willow with those growth characteristics would be suited to mine soil reclamation. Clones of Salix eriocephala, S. pupurea, S. miyabeana and S. sachalinensis and their hybrids are under continual development for high biomass yields and improved site tolerances (Smart et al., 2008).

Willow may be an ideal woody species to carry out the ecological goals of mine reclamation. As an early successional species, its fast growth caters to revegetation goals for bond release. Willow canopy and a dense root system contribute to erosion resistance. Canopy cover intercepts rainfall and slows its impact with the soil surface, reducing the mobilization of soil particles. Dense root systems within the upper $15 \mathrm{~cm}$ of soils retain soil particles against water movement (Kuzovkina and Volk, 2009). The aggressive nature of willow rooting has shown tolerance to compacted (high bulk density) soils and served to break dense soil structure (Kuzovkina et al., 2004). The loosened soil increases water infiltration and aids in reducing erosive overland runoff. Throughout its rotation, the willow crop will introduce organic matter and nutrients into the mine soil through root senescence and aboveground litterfall. Ericsson (1994) found that willow litter supplied up to two-thirds of willow's annual nutrient uptake which was measured to be $200 \mathrm{~kg} \mathrm{~N}, 30 \mathrm{~kg} \mathrm{P}$ and $150 \mathrm{~kg} \mathrm{~K}$ per hectare. The organic matter also serves to increase water holding capacity and improve the cation exchange properties of mine soils with little to no fine (silt and clay) content. In a plantation dedicated to long-term biomass production, these soil improvements will continually enhance performance. On sites planned for reforestation, willow can rebuild the soil to eventually favor late seral species that naturally colonize or are installed by successive planting efforts (Kuzovkina and Quigley, 2005). 


\section{Part II: Willow Cultivation}

\section{Standard SRWC Methods}

Optimum conditions for willow production have been determined through trials on agricultural soils. The greatest willow yields have been produced on soils with good aeration, consistent water availability and available nutrients (Abrahamson et al., 2010). Loamy soils were best, including silt loams, sandy loams and clay loams. Grain structure was well- developed to single-grained. The most productive soils were imperfectly to moderately well-drained. Acidity was slight ( $\mathrm{pH} 5.5$ ) to slightly alkaline ( $\mathrm{pH} 8.5$ ). The cultivated rooting zone was $46 \mathrm{~cm}$ or greater. Coarse, massive, or otherwise structure-less soils were deemed unsuitable. Excessively well drained, sandy, gravelly soils or poorly drained heavy clays did not support optimal willow growth.

Willow cropping developed into a double row system with planting density of

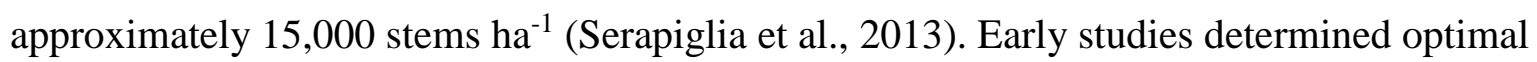
production at densities between 10,000 and 20,000 stems ha ${ }^{-1}$ (Willebrand et al., 1993). Standard spacing of the double row design was $0.76 \mathrm{~m}$ by $0.61 \mathrm{~m}$ within each paired row and $1.5 \mathrm{~m}$ between double rows (Fig. 1).

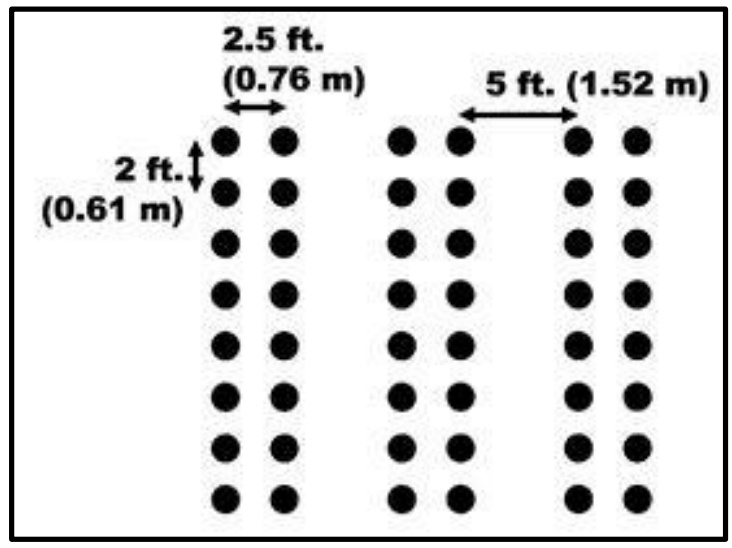

Figure 1. Conventional double-row willow cropping layout (Willowpedia) 
Plantation establishment included agricultural site preparation techniques such as weed control, plowing and disking. Weed competition has been cited as the leading factor in willow plantation failure (Abrahamson et al., 2010). Weed control with an appropriate herbicide mix was recommended between two and four weeks before plowing and disking. Liming was generally recommended to raise $\mathrm{pH}$ above 5.5. Planting occurs in the spring either manually or mechanically by a step-planter machine. Dormant stem cuttings of 10-20 cm length are vertically pushed into the soil. A pre-emergent herbicide was recommended immediately following planting to ensure competition control.

After the first growing season, following litter fall and before bud-swell, stems were coppiced (cut back) to between 2 and $4 \mathrm{~cm}$. Coppicing has been shown to eliminate apical dominance, promote multiple branching, and accelerate canopy closure (Keoleian and Volk, 2005). Fertilization at $100 \mathrm{~kg} \mathrm{~N} \mathrm{ha}^{-1}$ has been recommended at the beginning of the second growing season based on yield optimization studies (Keoleian and Volk, 2005). The first biomass harvest occurs in 3-4 years following coppicing when individuals are approximately $5 \mathrm{~m}$ in height (Abrahamson et al., 2010). Seven to ten biomass harvests may occur before productivity declines, at which point the plantation will require plowing under and reestablishment (Table 1).

\begin{tabular}{ccl}
\multicolumn{4}{c}{ Table 1. Typical short rotation willow harvest schedule (Keoleian and Volk, 2005). } \\
\hline Year & Season & \\
\hline 0 & Fall & Mow, contact herbicide, plow, disk, seed covercrop, cultipack \\
& Disk, cultipack, plant, pre-emergent herbicide, mechanical and/or herbicide weed \\
1 & Spring & control \\
1 & Winter & 1st year coppice \\
2 & Spring & Fertilize \\
4 & Winter & 1st harvest \\
5 & Spring & Fertilize \\
7 & Winter & 2nd harvest \\
$8-22$ & & Repeat 3 year cycle for 3rd-7th harvest \\
23 & Spring & Elimination of willow stools \\
\hline
\end{tabular}


Biomass yields under the SRWC system have reached 8 to 12 dry $\mathrm{Mg} \mathrm{ha}^{-1} \mathrm{yr}^{-1}$ in experimental plantations (Volk et al., 2016). Commercial yields were expected to be lower, in

the range of 5-15 $\mathrm{Mg} \mathrm{ha}^{-1} \mathrm{yr}^{-1}$ due to soil and site variations on large plantations (Stolarski et al., 2015). Methods for obtaining consistent, high commercial yields will result from continued development of cultural techniques and genotype selection. Deployment of improved willow cultivars that tolerate varied soil conditions will be key to obtaining consistently large, economically viable yields.

\section{Alternative Planting Methods}

Through efforts to streamline SRWC cultivation, a planting machine has been developed that lays willow 1-2 m long willow whips or $0.2 \mathrm{~cm}$ cuttings horizontally into a $5-15 \mathrm{~cm}$ deep soil furrow. Horizontal planting methods take advantage of the meristematic nodes on willow stems that produce roots or shoots depending on orientation, upward or downward. Yield trials have largely shown a positive correlation between cutting or whip length and yield. Larsen et al. (2014) observed comparable yields from $20 \mathrm{~cm}$ cuttings under both planting methods. Horizontally planted $10 \mathrm{~cm}$ cuttings yielded less. Continuously planted whips (planted end to end) yielded the greatest biomass. Edelfelt et al. (2015) experimented with cutting lengths of 25$200 \mathrm{~cm}$ and vertical and horizontal planting at depths from 5-17 cm. Their results corroborated the positive relationship of cutting length and biomass but indicated that vertically planted cuttings of produced more biomass for a given length. Planting depth results indicated that horizontally planted cuttings performed best at shallow depth. These results appeared to favor vertically planted cuttings in terms of biomass production and planting material required.

Some debate has occurred surrounding the establishment costs of horizontal planting. Researchers such as Lowthe-Thomas et al. (2010) have claimed that the materials preparation 
required for horizontal planting of willow whips offered up to $48 \%$ cost savings during plantation establishment. Biomass yield from lay-flat stems exceeded those planted vertically, which further justified horizontal planting. McCracken et al. (2010) contended that up to 330\% more planting material was used in horizontal planting of willow whips to obtain similar yield with vertical cuttings. This negated any establishment cost savings. Additionally, the shallower depths of horizontal planting $(5-10 \mathrm{~cm})$ may put horizontally planted willow at an initial disadvantage during drought conditions. On those grounds, McCracken et al. (2010) cautioned against horizontal planting as an economically viable method.

Economic debates aside, alternative planting methods have been seen by some as techniques to establish willow under challenging soil conditions. For agricultural applications, Lowthe-Thomas et al. (2010) documented a distinct advantage of the "layflat" planter in stony soils over the vertical step planter. The operability of a furrower was easier than pushing cuttings to full depth. On disturbed sites, willows have been planted horizontally for slope stabilization and stream-bank restoration (Kuzovkina and Quigley, 2005). Cao et al. (2011) successfully tested a horizontal planting method to remedy failure of vertically planted cuttings on dredge spoils. Their method was to lay down $25 \mathrm{~cm}$ long cuttings and cover them with a thin layer of soil. After 16 weeks they saw no difference in biomass accrual between vertically and horizontally planted cuttings. In that study, coarse root fraction was greater in horizontally planted cuttings and fine root fraction was comparable to vertically planted stems. Horizontally planted cuttings may not have had a disadvantage to access soil moisture. Results such as these provide some indication that horizontally planted willow cuttings may be a solution to difficult planting conditions on minesoils. 


\section{Improved Willow Breeding}

Modern SRWC willow plantations rely on genetically improved willow to achieve optimal yields. In the United States, developing effective clones started by adopting varieties from the Canadian breeding program for yield trials. However, many Canadian clones were found susceptible to leaf rust (Melampsora spp.) (Smart et al., 2008). Varieties from European breeding programs was also tested but failed due to lack of resistance to agricultural pests such as potato leafhopper (Empoasca fabae) (Smart and Cameron, 2008). These early failures highlighted the importance of testing genotypes prior to widespread planting. As such, the U.S. breeding program, spearheaded by researchers at the State University of New York College of Environmental Science and Forestry (SUNY-ESF) and Cornell University, has catalogued over 700 accessions of willow that are available for clone development (Smart et al., 2005). The species considered most promising for biomass production include Salix sachalinensis, $S$.

purpurea, S. miyabeana, S. eriocephala and S. viminalis. Clones of these species are the current focus of the breeding program (Smart and Cameron, 2008). The clones "SV1" (S. x dasyclados), “SX61" (S. sachalinensis), "SX64” (S. miyabeana), "S25” (S. eriocephala), and "94001” (S. purpurea) have served as parents for many experimental crosses (Serapiglia et al., 2013) (Table 2). 
Table 2. Commercially available willow clones for biomass production. (Abrahamson et al., 2010)

\begin{tabular}{cc}
\hline Variety & Species \\
\hline SV1 & Salix $\times$ dasyclados \\
S65 & Salix caprea \\
SX5 & Salix eriocephala \\
SX61 & Salix miyabeana \\
SX64 & Salix sachalinensis \\
Fish Creek & Salix miyabeana \\
Onondaga & Salix purpurea \\
Allegany & Salix purpurea \\
Sherburne & Salix purpurea \\
Canastota & Salix sachalinensis $x$ S. miyabeana \\
Tully Champion & Salix sachalinensis $x$ S. miyabeana \\
Owasco & Salix viminalis $x$ S. miyabeana \\
Otisco & Salix viminalis $x$ S. miyabeana \\
Fabius & Salix viminalis $x$ S. miyabeana \\
Truxton & Salix viminalis $x$ S. miyabeana \\
Oneida & Salix viminalis $x$ S. miyabeana \\
Millbrook & Salix purpurea $x$ S. miyabeana \\
Preble & Salix purpurea $x$ S. miyabeana \\
& Salix viminalis $x$ S. miyabeana \\
\hline
\end{tabular}

Willows readily hybridize and propagate easily. Researchers have taken advantage of this behavior and developed methods of artificial pollination to produce inter- and intra-specific crosses from the desired genotypes (Kopp et al., 2001). Researchers have noted a tendency for heterosis as a result of hybridization within Salix genus (Serapiglia et al., 2014). That is, hybrids exhibit phenotypes and growth traits from parents that improve vigor and productivity.

The resulting genetic crosses have achieved the main goal of willow breeding, to continually improve biomass yields. In the first yield trials of clones bred in 1998, the newly bred variety "9873-20" produced 35\% greater biomass than the reference variety "SV1" (S. dasyclados) (Smart and Cameron, 2008). Similarly, the "Tully Champion” (S. viminalis $x$ S. miyabeana) clone, produced in 1999 surpassed yield from "SV1" by 77\%. The demonstrated improvements of newly developed clones over older varieties garners support for a continual willow breeding program to optimize yields. 
Disease and pest resistance are components of developing high performing genotypes for field deployment. Fungal infection by leaf rust is of utmost concern. Serapiglia et al. (2013) indicated that varieties of S. eriocephala were least resistant to willow leaf rust (Melampsora spp.), while clones of the naturalized species $S$. purpurea displayed the least rust incidence. Comparably, Smart and Cameron (2008) cited extreme susceptibility of S. viminalis clones to the potato leafhopper aphid while the "Tully Champion" clone exhibited resistance. As of 2012 breeding efforts have produced "Preble" (Salix viminalis $\times$ S. miyabeana), the latest clone that delivered both high yields, 29\% greater than SX61, displayed rust resistance, and was not damaged by common pests in trials (Gouker et al., 2015).

Recent attention has focused on the correlation of genetic ploidy levels to biomass yields and site tolerances. Ploidy levels within the Salix genus range from diploid to dodecadiploid and species have the potential to hybridize across ploidy levels with controlled pollination (Serapiglia et al., 2014). Of the currently bred species, Salix sachalinensis, S. purpurea, S. eriocephala and S. viminalis are diploid genotypes. S. miyabeana is a tetraploid genotype. Hybrids of diploid crossed with tetraploid genotypes have produced triploid progeny like "Preble", "Tully Champion", and "Fabius" that have repeatedly produced greater yields than diploid clones (Fabio et al., 2017; Gouker et al., 2015; Serapiglia et al., 2014). Fabio et al. (2017) have particularly shown adaptability of triploid clones to a range of environment and climate across ten sites in New York, Connecticut, Vermont and Michigan in the United States and in Saskatchewan and Ontario, Canada. The use of widely adaptable, high yielding clones, may be advantageous for mine reclamation applications in West Virginia where climate conditions approximate those in more northern regions. 


\section{Willow Fertilization}

Standard willow cultivation practice recommends fertilization based on nitrogen as the limiting nutrient at a rate of $100 \mathrm{~kg} \mathrm{~N} \mathrm{ha}^{-1}$ upon plantation establishment and following harvests (Abrahamson et al., 2010). Fertilization has become an integral factor in biomass systems because of the potential to maximize yields (Adegbidi et al., 2003). Inorganic fertilizers can comprise $20 \%$ to $30 \%$ of willow production costs. Organic fertilizers such as sewage sludge and manure may reduce that cost fraction based upon proximity of the material source to the planting location. Sevel et al. (2014) have shown comparable growth improvement with the addition of both organic and inorganic fertilizers at the same elemental rates.

Numerous studies (Adegbidi et al., 2003; Ledin, 1996; Kopp et al., 1996; Aronsson and Rosenqvist, 2011) have shown increased yields under fertilization. However, Adegbidi et al. (2003) noted that applications of nitrogen fertilizer above $100 \mathrm{~kg} \mathrm{~N} \mathrm{ha}^{-1}$ provided no benefits to yield after a three-year growing cycle. Aronsson and Rosenqvist (2011) recommended limiting applications to 60,100 , and $60 \mathrm{~kg} \mathrm{~N} \mathrm{ha}^{-1}$ in years $1-3$, respectively or applying a single $160 \mathrm{~kg} \mathrm{~N}$ $\mathrm{ha}^{-1}$ intensive application based on the economic balance between increased yield and fertilizer costs. Recommendations by Ericsson (1994) are on the same order at 114, 106, and $60 \mathrm{~kg} \mathrm{~N} \mathrm{ha}^{-1}$ during years 1 to 3 , respectively.

Ericsson's (1994) recommendations were based his on study of nitrogen allocation and cycling in willow plants. High nitrogen concentration was a prerequisite for achieving fast growth rate and high yields of aboveground biomass. Biomass growth and nitrogen requirement were positively correlated. Leaf growth was positively related to stem growth. Leaves in young plantations contained $75 \%$ of a willow's aboveground nitrogen, and $60 \%$ in established plantations. Nitrogen was required rates of 150 to $200 \mathrm{~kg} \mathrm{ha}^{-1} \mathrm{yr}^{-1}$ for leaf growth in established 
willow plantations. One-third to two-thirds of this requirement may be provided through nutrient translocation at leaf senescence. The remaining nutrient fraction must be provided by translocation within the plant, fertilization, or the soil to continue biomass accrual at the desired rate.

\section{Carbon Allocation Patterns}

Attaining large allocation to harvestable stems relative to root and leaf structures is important to producing large SRWC willow yields. Previous studies have linked allocation patterns to environmental conditions, including water availability, nutrient availability, soil textures and genotypes (Weih et al., 2011; Poorter et al., 2012). Commonly, biomass partitioning has been shown as a response to resource availability. That is, under stress for soil-bound resources, allocation to roots will increase whereas under stress for atmospheric resources, light or $\mathrm{CO}_{2}$, allocation will shift to aboveground growth. However, several studies have looked at confounding factors including soil physical properties and plant genotypes that may alter the expected biomass partitioning. The common denominator is that a plant's belowground portion must support the function and growth of its aboveground components under the prevailing environmental conditions.

For example, in their greenhouse study on shrub willow, Weih et al. (2011) demonstrated that under drought conditions, photosynthate was predominately allocated to root growth in order to expand absorption surface. Allocation to roots was at the expense of leaf biomass. Plants allocating less to leaf area growth transpired less in water-limited conditions. As a result of limited leaf growth, photosynthetic production did not favor accrual of aboveground shoot biomass.

Trees under nutrient stress exhibited similar biomass allocation to trees under drought conditions. Allocation to roots was emphasized at the expense of aboveground accrual. Ericsson 
et al. (1996) found that $60-70 \%$ of annual carbon was allocated to root production under nutrient limitations. Nitrogen supply is of particular importance because it is directly utilized in leaf and chlorophyll production. Phosphorous, magnesium, and sulfur are also involved in photosynthetic reactions. Deficiencies in these elements cause relative increases in root biomass components. Proportionally, root growth is the least suppressed when the formation of new tissues is limited by mineral nutrients (Ericsson et al., 1996).

\section{Predicted Experimental Outcomes}

Based on the preceding literature review the following hypotheses were developed. It was expected that one clone will have superior survival, growth and biomass production depending on establishment practices. The horizontal planting method was expected to create easier planting for manual operations but not to promote a high survival rate for individuals compared to vertical planting. Fertilizer was expected to enhance plant height and diameter growth, and biomass production across all treatments. However, the effects of traditional fertilizer versus controlled release fertilizer were not expected to be significantly different. Clones were expected to differ in biomass allocation to shoots versus leaves.

\section{MATERIALS AND METHODS}

\section{Site Description}

The C-1 surface mine is located near Mount Storm, Grant County, WV (39.133639,79.281323). The site was mined for the Elk Lick, Bakerstown, and Mahoning coal seams. Elevation at the site is approximately $1065 \mathrm{~m}$ with a northern aspect. The site is in USDA plant hardiness zone 5b. Overburden material was a mixture of shales and sandstones of the Conemaugh Group from the Pennsylvanian Period. The surface was prepared with a weathered 
brown sandstone topsoil substitute that was rough graded by bulldozer. Soils were amended and hydro-seeded in September 2014 as shown in Tables 3 and 4.

Table 3. Reclamation soil amendments applied to minesoils at the C-1 mine.

\begin{tabular}{|c|c|}
\hline Soil Amendment & Rate \\
\hline & ------------- $\mathrm{kg} \mathrm{ha}^{-1}$ \\
\hline Lime & 5,000 \\
\hline Mulch & 2,200 \\
\hline Nitrogen & 100 \\
\hline Phosphorus as $\mathrm{P}_{2} \mathrm{O}_{5}$ & 220 \\
\hline Potassium as $\mathrm{K}_{2} \mathrm{O}$ & 220 \\
\hline
\end{tabular}

Table 4. Reclamation seed mix applied to minesoils at the C-1 mine.

\begin{tabular}{lc}
\hline Seed & Rate \\
\hline & $---------\mathrm{kg} \mathrm{ha}^{-1}------------$ \\
Birdsfoot Trefoil (Lotus corniculatus L.) & 17 \\
Orchard Grass (Dactylis glomerata L.) & 17 \\
Red Top (Agrostis gigantea Roth) & 6 \\
Oats/Perennial Rye/Japanese Millet (Avena sativa / Lolium & 50 \\
perenne L./ Echinochloa esculenta) & \\
\hline
\end{tabular}

Soils at the site are coarse textured and classify as sand by USDA textural classes (Daniels and Haering, 2006). Figure 2 shows the grain size distribution at the site. Composition was determined from six soil samples taken from 0 to $30 \mathrm{~cm}$ depth across the experimental plots. Soil composition was approximately $60 \%$ gravel, $30 \%$ sand and $10 \%$ silt and clay by mass (ASTM International, 2009). Soil bulk density was measured at $1.5 \mathrm{Mg} \mathrm{m}^{-3}$ by the excavationwater method (Page-Dumroese et al., 1999). 


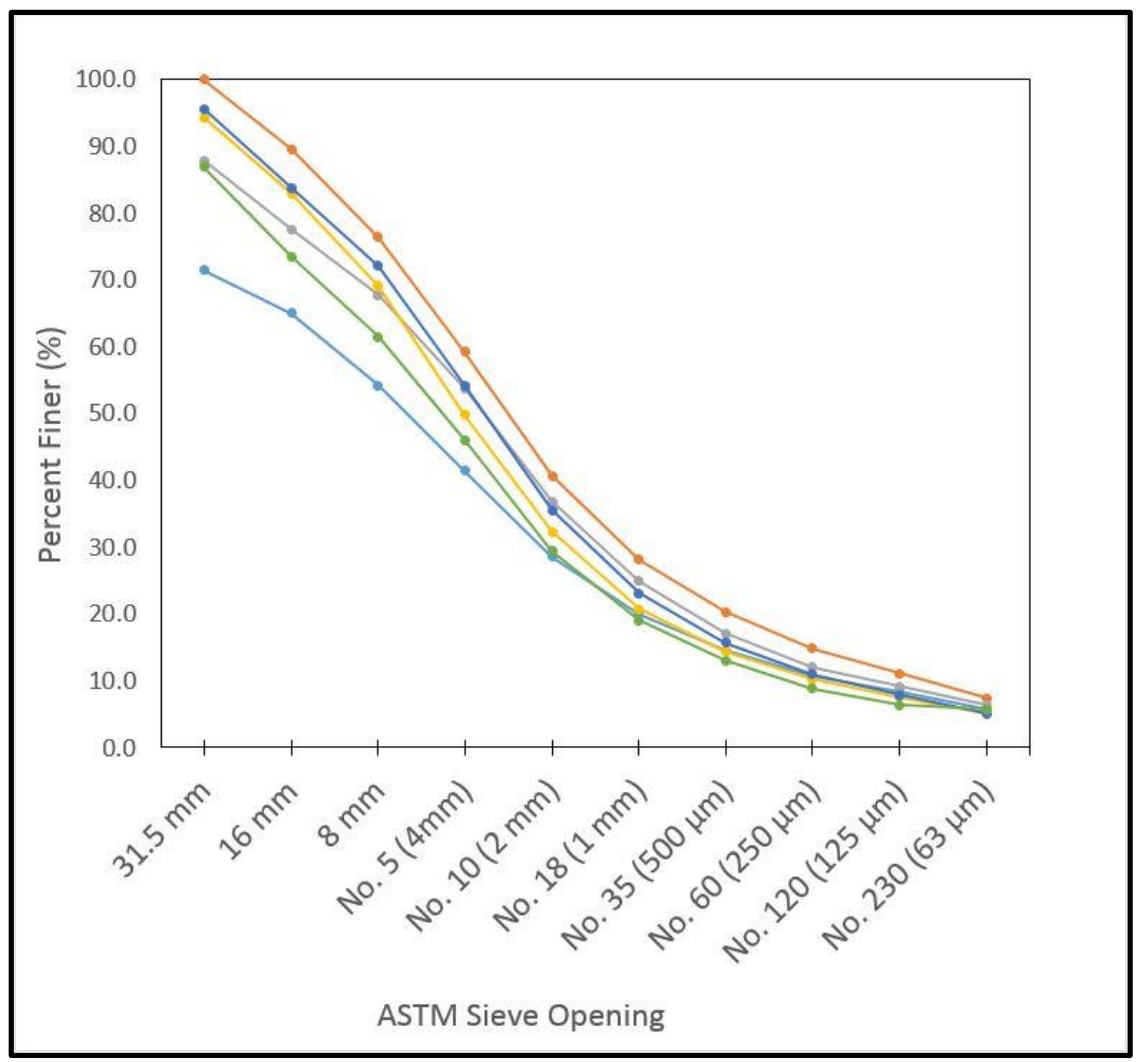

Figure 2. Grain size distribution showing results of six grain size tests, $0-30 \mathrm{~cm}$ depth, on minesoils within the willow planting area.

Results from twelve soil samples taken from 0 to $30 \mathrm{~cm}$ depth across the experimental plots in May 2015, prior to fertilizer treatments, and analyzed by the West Virginia University Soil Testing Lab using Melich 1 extraction indicated an average soil $\mathrm{pH}$ of 4.6 and average cation exchange capacity of $12.5 \mathrm{meq} 100 \mathrm{~g}^{-1}$. Nutrient levels are documented in table 5 .

Table 5. Mean nutrient levels from twelve soil tests taken at 0-30 cm depth across experimental willow plots in May 2015.

\begin{tabular}{lc}
\hline Nutrient & Mean Value \\
\hline & $\mathrm{P}_{2} \mathrm{O}_{5}$ \\
$\mathrm{~K}_{2} \mathrm{O}$ & 110 \\
$\mathrm{Ca}$ & 33 \\
$\mathrm{Mg}$ & 618 \\
\hline
\end{tabular}

At the recommendation of Albertsson et al. (2014), willow establishment required control of competing vegetation in the vicinity of plantings. Competition from broadleaves was 
controlled with pre-emergent herbicide application of oxyflourfen (Goal 2XL; Dow Agrosciences) at a rate of $4.7 \mathrm{~L} \mathrm{ha}^{-1}$. Grasses were controlled with pre-emergent application of glyphosate (Roundup; Monsanto Company) at a rate of $7 \mathrm{~L} \mathrm{ha}^{-1}$. Post-emergent grass competition was controlled with sethoxydim (Poast; BASF Company) at a rate of $1.5 \mathrm{~L} \mathrm{ha}^{-1}$. Water was the carrier for all herbicides. No surfactants were used.

Weather data was acquired from the National Weather Service station at Bayard, West Virginia, approximately $24 \mathrm{~km}$ to the northwest of the C-1 mine (AgACIS, 2016). During the 2015 growing season, average temperature for the April through September period was $15.8^{\circ} \mathrm{C}$, $0.6{ }^{\circ} \mathrm{C}$ greater than normal. Precipitation throughout the period was $2.6 \mathrm{~cm}$ greater than normal with notable below-normal periods in May $(7.1 \mathrm{~cm}$ below normal) and July $(3.0 \mathrm{~cm}$ below normal). The 2016 growing season saw an average temperature of $16.1^{\circ} \mathrm{C}, 0.9^{\circ} \mathrm{C}$ greater than normal. Precipitation for the 2016 growing season was $5.3 \mathrm{~cm}$ below normal with the driest periods occurring in April (2.0 cm below normal), July (6.2 cm below normal) and August (4.4 cm below normal).

\section{Experimental Design}

Willow clones selected for this study were SX61 (Salix sachalinensis), Fish Creek (Salix purpurea), and Preble (Salix viminalis $x$ S. miyabeana). The clones are promoted by the SUNY ESF and Cornell as fast growing and high yielding, suitable for bio-energy applications. According to their respective fact sheets, all clones are "adaptable to a wide range of soil and moisture conditions" and "[prefer or require] maximum sunlight" (Cameron et al., 2007; Gouker et al., 2015). SX61 is a variety native to Asia. Fish Creek is a cross between two S. purpurea cultivars that reportedly produced $30 \%$ greater biomass than its parents. Preble reportedly produced 18\% greater biomass than SX61 (Gouker et al., 2015). 
Three treatment factors were arranged in a split plot design. Twelve whole plots each consisted of 60 willow cuttings planted in double row arrangement at a spacing of $0.76 \mathrm{~m}$ between paired rows and $0.61 \mathrm{~m}$ down rows (Fig. 3). Spacing between double rows was $3.6 \mathrm{~m}$. The three fertilization treatments, no fertilizer, coated fertilizer and standard fertilizer, were administered at the whole-plot level and replicated four times. Fertilizer was applied at the beginning of the first growing season during the third week in May 2015. Fertilizer was obtained from the Southern States Cooperative (Morgantown, WV). Equal applications of standard 10-1010 fertilizer or sulfur-coated 10-10-10 slow release fertilizer was administered at a rate of $140 \mathrm{~kg}$ $\mathrm{N} \mathrm{ha}^{-1}$ (Kopp et al., 1996). Within each whole plot, six sub-plots were assigned to three clones and two planting methods in factorial arrangement (Fig. 3). Each sub-plot consisted of ten willow cuttings.

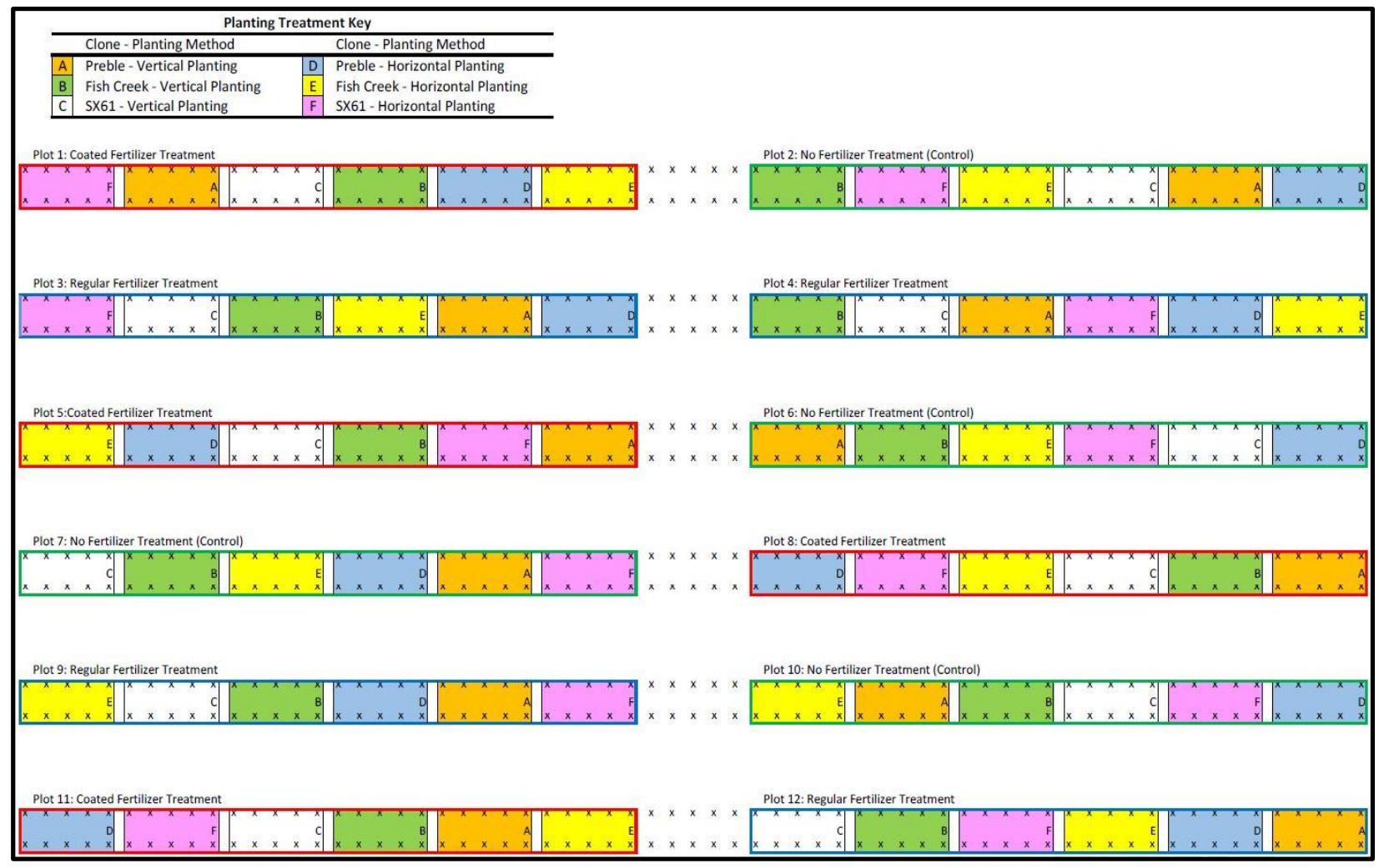

Figure 3. Willow planting layout showing four experimental replicates. Crosses indicate individual willow plants Main plot fertilizer treatments are identified. Sub-plot labels/colors indicate the assigned clone and planting method. 


\section{Measurements}

Survival of individual plants was assessed in September of 2015 and August of 2016 for each of the 720 cuttings. Measurements of total plant height and basal diameters of each stem were taken in August 2016 (Mosseler et al., 2014a). Height measurements were taken to the nearest centimeter. Basal diameters were measured at point of attachment with digital calipers to $0.1 \mathrm{~mm}$. Data from living stems were averaged by subplot to ascertain the mean maximum plant height and mean largest shoot diameter for analysis. Total cross sectional area of shoots per cutting (basal area) was also calculated from diameter measurements. Total basal areas were averaged by each subplot treatment for analysis.

Biomass was measured by destructive harvesting of the two center-most plants per subplot. Sampling was performed in August 2016 (the end of the second growing season). Harvested individuals were cut $3 \mathrm{~cm}$ above the ground line. Samples were individually labeled and bagged for transport to the lab. Biomass samples were dried at $65^{\circ} \mathrm{C}$ for 72 hours and weighed. Aboveground portions were separated into shoots and leaves to determine the individual biomass allotted to each structure. Shoot and leaf biomass data were averaged by sub-plot. Leaf to shoot mass ratios were developed for each plot to assess the efficiency of shoot growth.

Willow shoot biomass measurements were scaled up to a per-hectare basis using a planting density of 15,000 cuttings per hectare and adjusted by the survival percentages for each clone (Serapiglia et al., 2013).

\section{Statistical Analyses}

Statistical analyses were performed using SAS ${ }^{\circledR} 9.4$ software (SAS Institute Inc., 2014). Survival data were analyzed by logistic regression (logistic procedure), expanded model (Eq. 1).

$$
P_{S}=\frac{e^{\left(\beta_{o}+\beta_{1} x_{1}+\ldots+\beta_{n} x_{n}\right)}}{1+e^{\left(\beta_{o}+\beta_{1} x_{1}+\ldots+\beta_{n} x_{n}\right)}}
$$


where:

$P_{s}=$ probability of survival

$\beta_{i}=$ regression coefficients

$X_{i}=$ independent variables

The binary variables "survived" versus "planted" were compared among three classes representing the treatment structure, fertilizer, planting position, clone, plus a fourth class for time of measurement, 2015 and 2016. Pairwise comparisons of treatments that showed significant difference were carried out by chi-square tests on least square means slices.

Second year total plant height, maximum stem diameter, and total basal were compared among treatments. Comparisons were made by analysis of variance (ANOVA) using the glimmix procedure with the random effect of replication on the whole plot treatment (fertilizer). Subsequent pairwise comparisons of treatments showing significant difference at the $95 \%$ level were made with Tukey-Kramer adjustment for multiple comparisons. Shoot and leaf biomass data, as well as leaf- to shoot ratios were compared among treatments after the second growing season by the same analyses.

\section{RESULTS}

\section{Survival}

Survival decreased over time $(\mathrm{p}<0.0001)$ across all treatments. Overall survival in year one was $80 \%$ and decreased to $64 \%$ after year two. In both years, the survival was affected by planting position $(\mathrm{p}<0.0001)$, clone $(\mathrm{p}<0.0001)$, and an interaction of fertilizer and clone treatments $(\mathrm{p}<0.0001)$. Fertilizer by itself was not a significant factor for cutting survival. By the end of the second growing season, vertically planted cuttings had twice the survival of horizontally planted cuttings, $83 \%$ versus $46 \%$, respectively. Survival differences among clones were driven by the relatively low survival of the Fish Creek variety (Fig. 4). Survival of Fish Creek clones were 44 and 29\% lower compared to Preble $(p<0.0001)$ and SX61 (p = 0.0002), 
respectively. The large decline in survival from 2015 to 2016 for the Fish Creek clone was notable. Survival of Preble and SX61 remained relatively stable over the same time period.

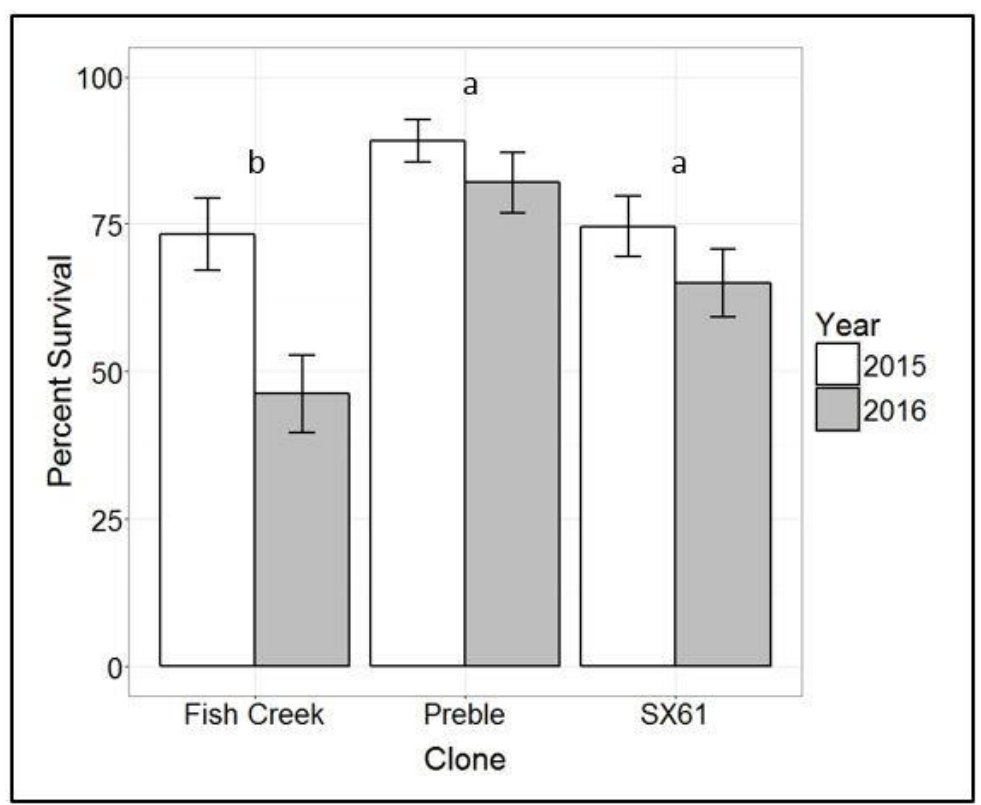

Figure 4. Percent survival of willow in two growing seasons summarized by clone. Error bars denote standard error around the mean. Results displaying different letters denote statistical difference at $p=0.05$ level.

The interaction of fertilizer and clone effects $(\mathrm{p}<0.0001)$ originated from the inconsistent survival rates for the Fish Creek and SX61 clones, relative to the Preble clone under the three fertilizer treatments (Fig. 5). For coated fertilizer, survival of Fish Creek was less than Preble $(\mathrm{p}<0.0001)$ and SX61 ( $<$ 0.0001). Under no fertilizer application, Fish Creek survival was greater than SX61 $(p=0.0483)$ and Preble survival was greater than SX61 $(p=0.0026)$. The Preble clone achieved consistently high survival (greater than 75\%) across all fertilizer treatments. Preble had a clear survival advantage with regular fertilizer treatment whereas survival was similar to Fish Creek under no fertilizer treatment and similar to SX61 with coated fertilizer treatment. 


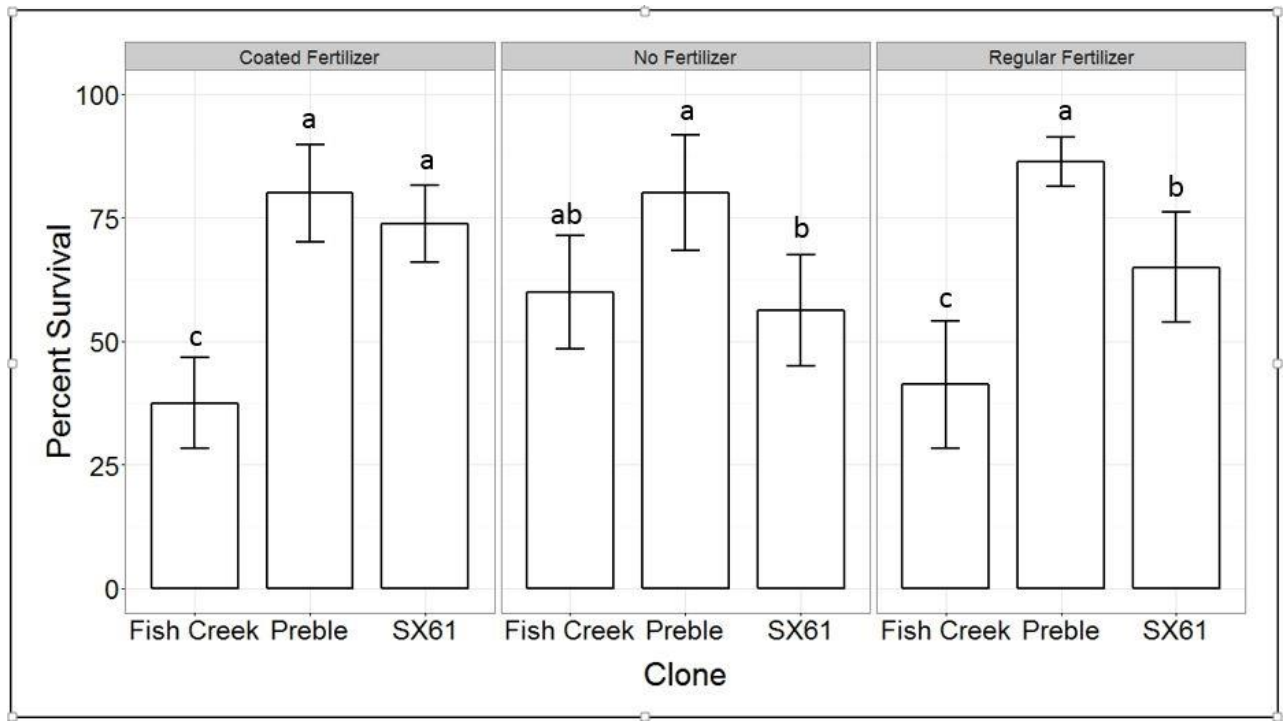

Figure 5. Percent survival of fertilized willow clones following the second growing season. Error bars denote standard error around the mean. Results displaying different letters denote statistical difference at $p=0.05$ level.

Vertically planted cuttings of Preble $(\mathrm{p}<0.0001)$ and SX61 clones $(\mathrm{p}=0.0002)$ had greater survival relative to Fish Creek cuttings (Fig. 6). Among planting and clone treatments $(\mathrm{p}=0.0179)$, horizontally planted Fish Creek and SX61 each had greater than $50 \%$ mortality compared to vertically planted cuttings. By contrast, horizontally planted Preble clones exhibited less than $25 \%$ reduction in survival compared to vertical. 


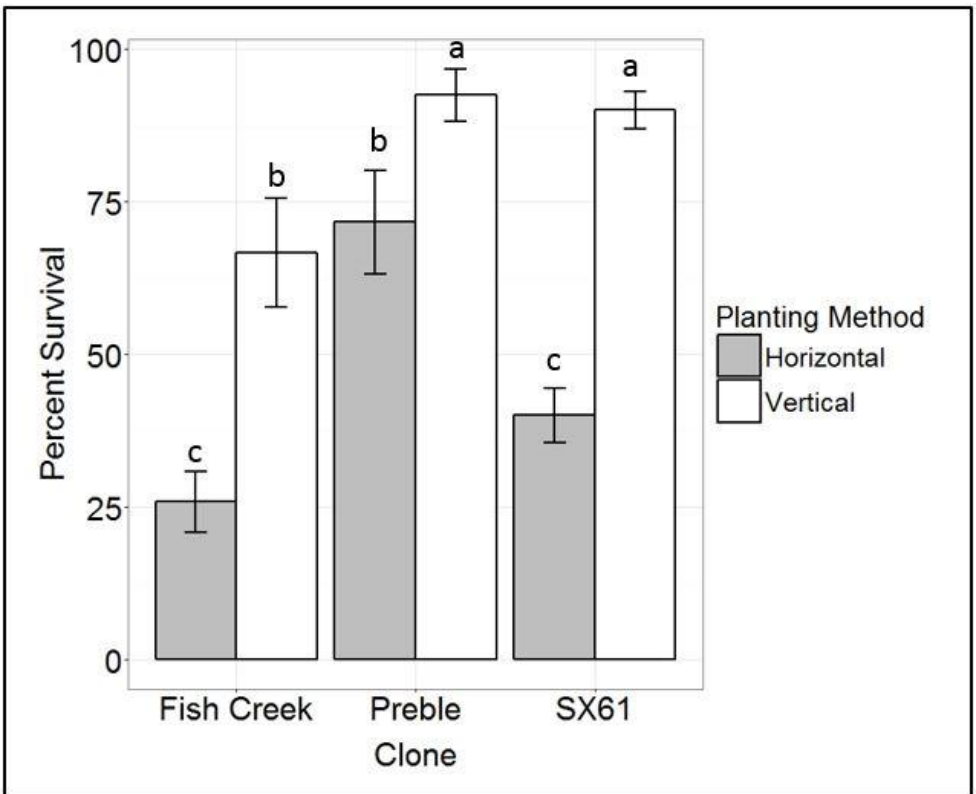

Figure 6. Percent survival of willow after two growing seasons compared by planting method. Error bars denote standard error around the mean. Results displaying different letters denote statistical difference at $p=0.05$

\section{Growth Metrics}

The clone factor consistently produced a main treatment effect across all growth measurements. Measures of total plant height, total basal area, and aboveground biomass differentiated solely by clone. Maximum stem diameters were influenced primarily by clone and planting method and by the interaction of clone and fertilizer effects.

Differences in total plant height were associated with clones $(\mathrm{p}=0.0328)($ Fig. 7$)$. Height of the Preble clone clearly exceeded Fish Creek after two growing seasons $(p=0.0311)$. However, SX61 did not show a clear performance advantage over Fish Creek nor disadvantage to Preble in height growth. 


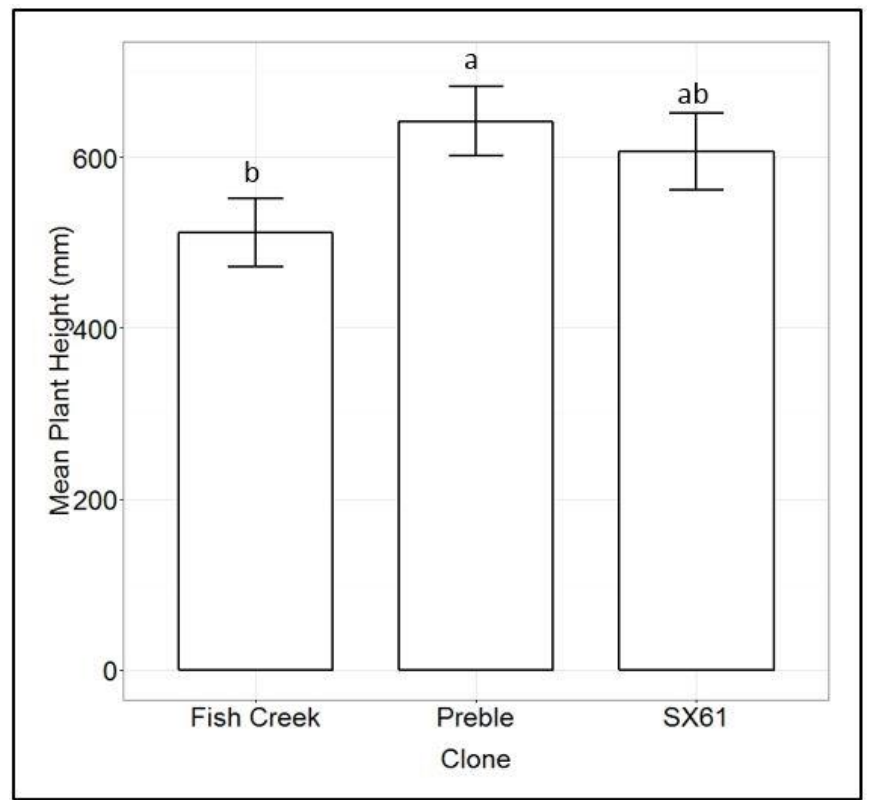

Figure 7. Mean Plant height of willow after two growing seasons summarized by clone. Error bars denote standard error around the mean. Results displaying different letters denote statistical difference at $p=0.05$ level.

Maximum stem diameters varied among clone $(\mathrm{p}<0.0001)$. Differences between planting methods $(\mathrm{p}=0.0462)$ and an interaction between the effects fertilizer and clone treatment $(\mathrm{p}=0.0235)$ were also indicated by the analysis. For the planting treatments, horizontally planted stems were $0.7 \mathrm{~mm}$ larger than vertically planted stems (Fig. 8). Preble clones had 3 to $4 \mathrm{~mm}$ greater maximum stem diameters than SX61 and Fish Creek, respectively, while SX61 was $1 \mathrm{~mm}$ larger than Fish Creek $(\mathrm{p}=0.0425)$ (Fig. 9). 


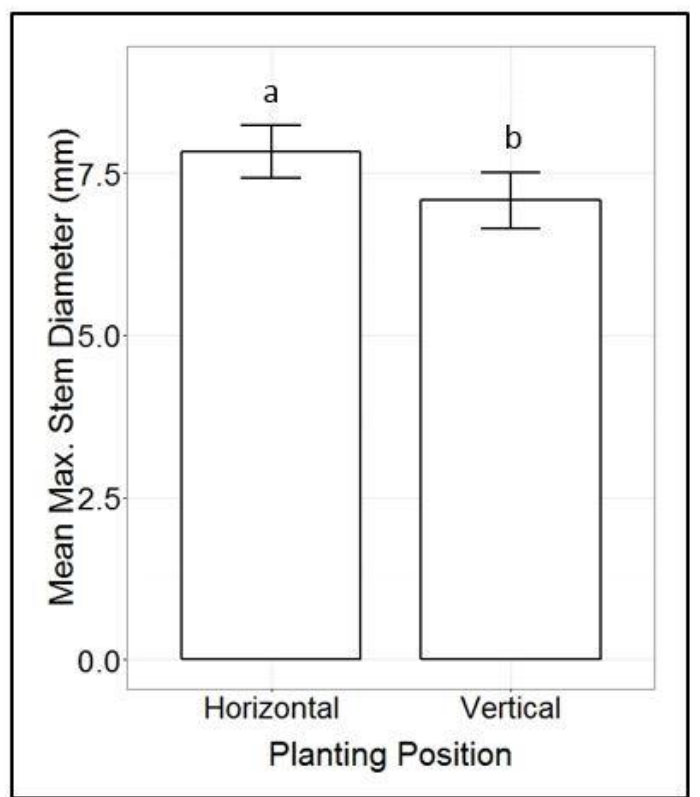

Figure 8. Mean maximum stem diameter after two growing seasons for willow planted horizontally or vertically. Error bars denote standard error around the mean. Results displaying different letters denote statistical difference at $p=0.05$

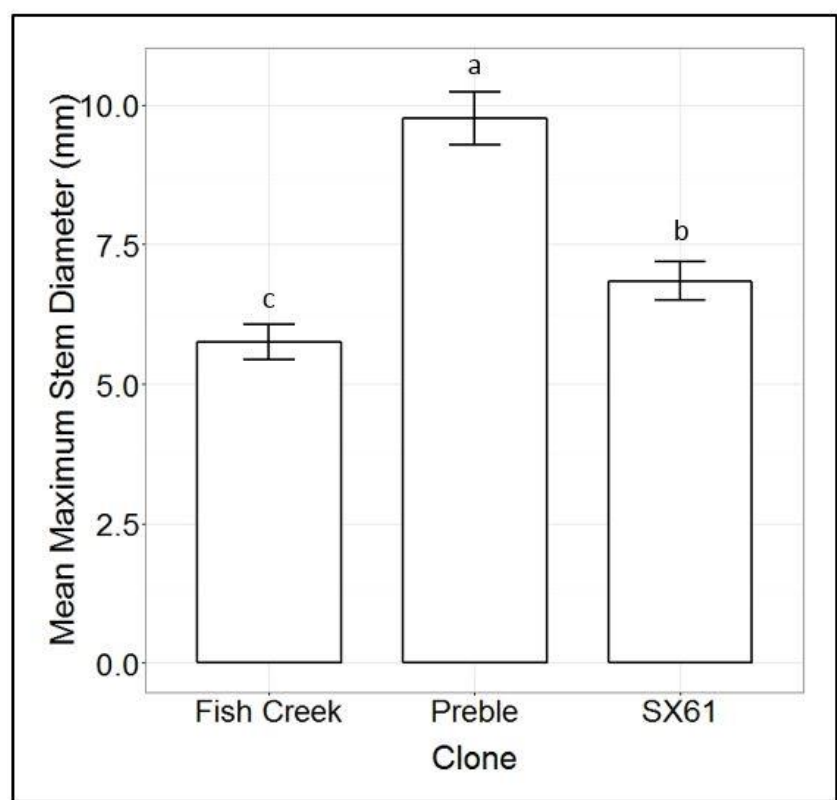

Figure 9. Mean maximum stem diameter of willow plants after the second growing season for each clone. Error bars denote standard error around the mean. Results displaying different letters denote statistical difference at $p=0.05$ level.

The interaction of fertilizer and clone treatments was significant for maximum stem diameter $(\mathrm{p}=0.0433)$ (Fig. 10). Stem diameter was consistently the smallest for the Fish Creek clone across all three fertilizer treatments, whereas the Preble clone was always among the largest. However, SX61 did produce similar maximum stem diameters to Preble under coated fertilizer treatment. Preble shoot diameter was most influenced by regular fertilizer treatment and produced $77 \%$ larger under regular fertilizer treatment compared to other clones. 


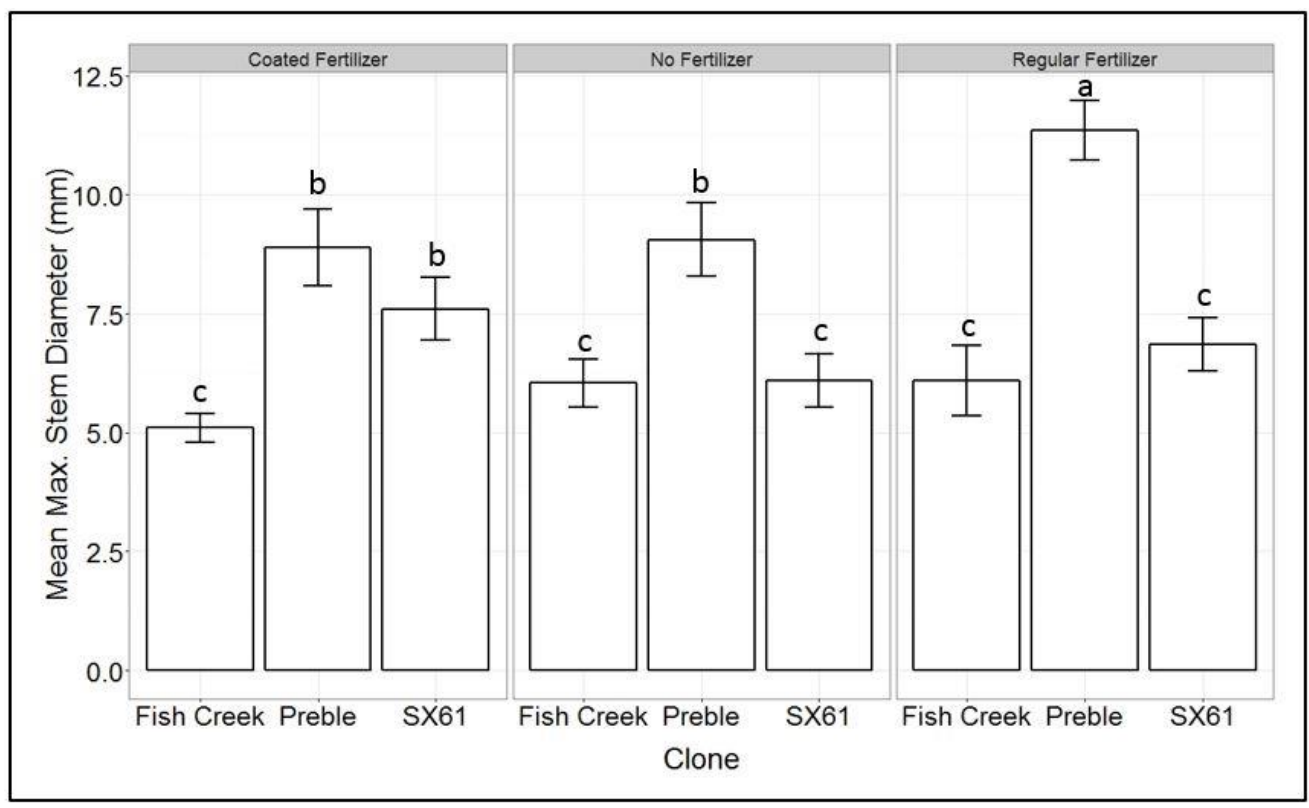

Figure 10. Mean maximum stem diameter of willow after the second growing season compared by the interaction of fertilizer and clone effects. Error bars denote standard error around the mean. Results displaying different letters denote statistical difference at $p=0.05$ level.

When total basal area was calculated for each stool, clone emerged as the only influential treatment $(\mathrm{p}<0.0001)$ (Fig. 11). Preble stools had at least twice the basal area relative to the other clones. Basal areas of SX61 stools were the second largest, exceeding Fish Creek area by $33 \mathrm{~mm}^{2}(\mathrm{p}=0.0227)$. 


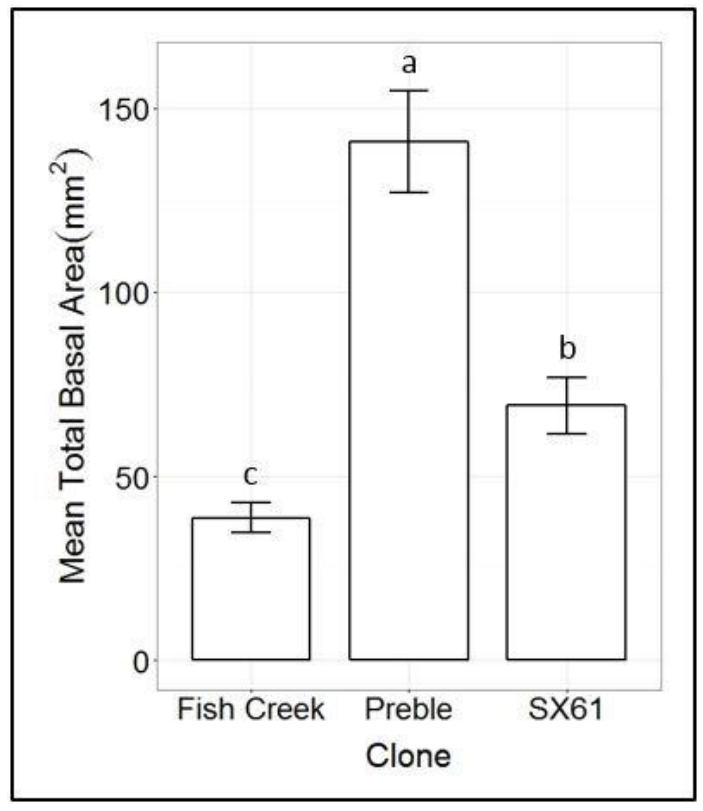

Figure 11. Total basal area of willow stools after two growing seasons for each clone. Error bars denote standard error around the mean. Results displaying different letters denote statistical difference at $p=0.05$ level.

\section{Biomass}

In our study, aboveground biomass production through the second growing season depended solely on clone $(\mathrm{p}<0.0001)$. Leaf mass and shoot mass were analyzed separately then compared as leaf-to-shoot ratios (Table 6). Preble stems grew the greatest mean leaf mass, greatly exceeding the leaf production of Fish Creek by $11.5 \mathrm{~g}(\mathrm{p}<0.0001)$ and SX61 by $7.9 \mathrm{~g}(\mathrm{p}$ $=0.0053)$.

Table 6. Aboveground biomass partitioning of willow. Values in parenthesis are standard errors. Letters indicate statistically different values.

\begin{tabular}{lccc}
\hline & \multicolumn{2}{c}{ Mean Mass } & \\
Clone & Leaf & Shoot & Leaf:Shoot Ratio \\
\hline & $-----\mathrm{g}-----$ & $-----\mathrm{g}------$ & $-----\mathrm{g} \mathrm{g}^{-1}---------$ \\
Fish Creek & $0.7(0.3) \mathrm{b}^{\dagger}$ & $3.3(0.8) \mathrm{b}$ & $0.10(0.03) \mathrm{b}$ \\
Preble & $12.2(2.7) \mathrm{a}$ & $26.9(6.8) \mathrm{a}$ & $0.43(0.04) \mathrm{a}$ \\
SX61 & $4.7(1.4) \mathrm{b}$ & $8.1(2.4) \mathrm{b}$ & $0.41(0.08) \mathrm{a}$ \\
\hline
\end{tabular}

$\dagger$ Values followed by the same letter not significantly different at $p=0.05$ level. 
Shoot mass production differentiated similarly to leaf mass production, by clone $(\mathrm{p}=$ 0.0003). Preble stems grew $23.6 \mathrm{~g}$ more dry mass than Fish Creek $(\mathrm{p}=0.0004)$ and $18.8 \mathrm{~g}$ more than SX61 $(p=0.0051)$. Leaf to shoot ratio $(\mathrm{LSR})$ varied by clone $(\mathrm{p}<0.0001)$. Preble and SX61 had a relatively similar mean LSR, 0.43 and 0.41 , respectively, while the LSR of Fish Creek clones was about $25 \%$ less.

Shoot biomass measurements have been scaled-up to project dry yields on a per-hectare basis for growth after two growing seasons and as annual yield (Table 7). Preble stand-level biomass yielded over 3 times more than the other two clones.

Table 7. Projected willow biomass yields at the C-1 mine after two seasons of growth.

\begin{tabular}{lcc}
\hline Willow Clone & Biennial Dry Yield & Annual Dry Yield \\
\hline & --- Mg ha $^{-1}$------ & Mg ha $\mathrm{yr}^{-1}-----$ \\
Preble & 0.34 & 0.17 \\
SX61 & 0.10 & 0.05 \\
Fish Creek & 0.04 & 0.02 \\
\hline Mean & 0.16 & 0.08 \\
\hline
\end{tabular}

\section{DISCUSSION}

The experiment at the $\mathrm{C}-1$ surface mine worked to characterize the potential for willow crop development on surface mine sites in West Virginia that are prepared by loose grading of a brown sandstone soil substitute. We were able to test willow performance under the conditions of a newly reclaimed mine where the shrubs were subjected to the environmental conditions associated with coarse-textured and rocky soils. Plants endured periods of drought, soil saturation, erosion, snowpack and snowmelt in the exposed mountain top environment at 1065 $\mathrm{m}$. The greatest achievement was attaining rates of willow survival greater than previously demonstrated on West Virginia minesoils by studies (e.g. Nobert et al. (2016)). Patterns of survival allowed us to narrow our recommendations against alternative planting methods and to favor the Preble and SX61 clones. As expected, willow growth was slow compared to willow 
plantations on agricultural soils (Mosseler et al., 2014b). But the observed growth patterns enabled us to further our understanding of clone performance and provide insight into the benefits of fertilizer application in the establishment year. Biomass production was not at harvestable nor economically viable levels after two growing seasons. However, the findings of the study did represent improvements over previous SRWC studies on West Virginia surface mines and provided insight that may be used to guide future SRWC trials for biomass production on reclaimed land.

\section{Survival}

Willow survival on the mine soil behaved as expected over the two year growth period. Survival rates of the clones tried at Mt. Storm ranged from $46 \%$ to $82 \%$, comparable to other trials on mine soils after two growing seasons. Mosseler et al. (2014a) documented survival of seven willow species (20 clones) between $20 \%$ and $82 \%$ on crushed shale mine overburden in

New Brunswick, Canada. Similarly, Casselman et al. (2006) saw survival rates of hybrid poplar (Populus spp.) of $41 \%$ and $72 \%$ on mines in West Virginia and Virginia where overburden was composed of shale and sandstone topsoil substitutes, respectively. Survival of the willow plantation was influenced by planting method, fertilizer, clone-specific adaptations, and the adverse growing conditions of the mine soil. Horizontal planting was not advantageous, superior clones emerged, and fertilizers provided a slight advantage to some clones on the basis of survival.

The shallow, horizontal planting method contributed heavily to mortality. In the establishment year, horizontally planted cuttings were observed prematurely drying before sufficient root propagation (Fig. 12). McCracken et al. (2010) noted similar susceptibility to drying in horizontally planted cuttings in an agricultural plantation at the Northern Ireland 
Horticulture and Plant Breeding Station in Armagh, Ireland. Cuttings that survived the first growing season at Mt. Storm were subject to the erosive forces of spring snowmelt and rains which were observed to transport soil from the willow plantation area, exposing horizontal cuttings and root systems which led to increased mortality. The contrastingly higher survivability of vertically planted cuttings, $83 \%$ after year two, indicated that this planting method was more suitable for the erodible and well drained conditions of the mine soil. The planting depth achieved by vertically planted cuttings, even in cases where full-depth planting was not achieved due to rocky conditions allowed roots access to soil water that was held below the soil surface during dry periods. Roots of horizontally planted cuttings needed to propagate through dry, dense soils in order to access deeper soil water which likely caused inadequate water uptake for some plants and eventual mortality. The depth of vertically-planted root systems also provided inherent resistance to the soil erosion that was observed across the entire plantation site. The horizontal planting method tried in this study was therefore unsuccessful on the basis of increased mortality and the horizontal planting methods used in this study will not be recommended to ease planting operations on coarse, rocky minesoils.
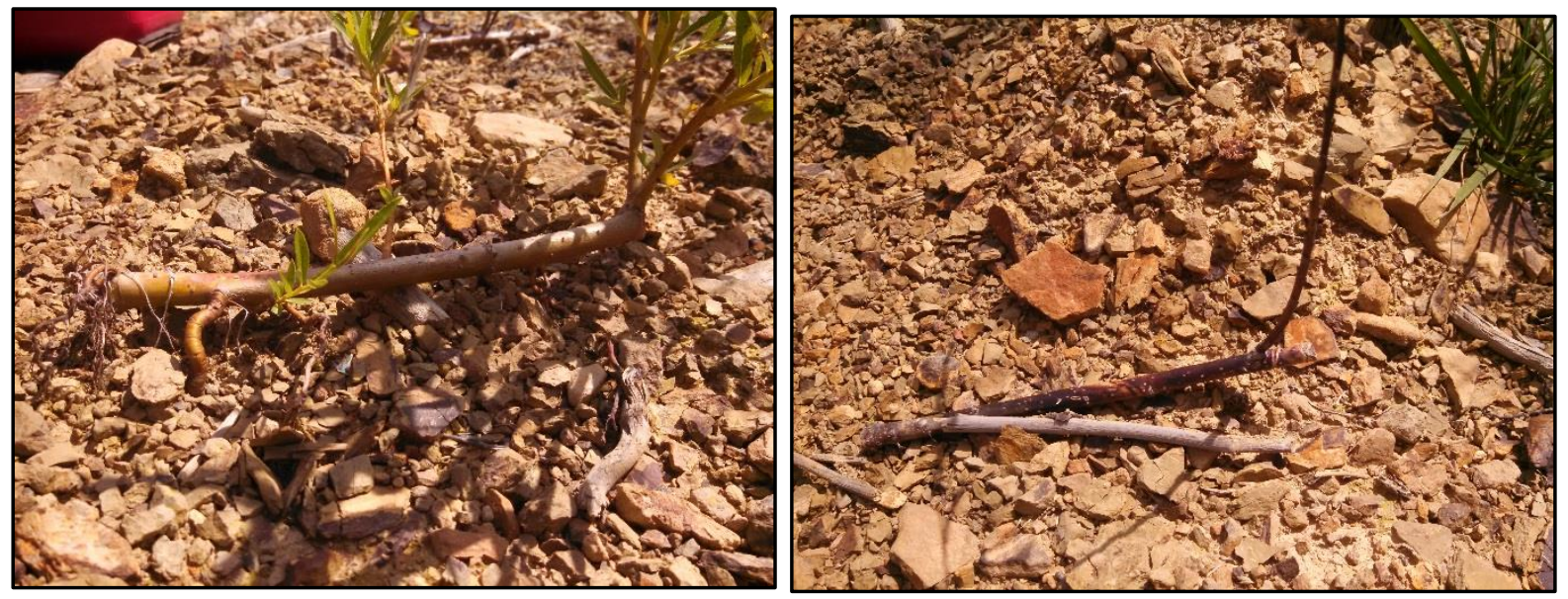

Figure 12. Horizontally planted willow cuttings, live (left) with exposed root system and dead (right) from exposure. 
Survival of the three clones provided insight in to their respective adaptations to the site conditions. Over 50\% of Preble and SX61 cuttings survived and grew through the second year whereas fewer than half of the Fish Creek shrubs survived. These results were more positive than Nobert et al. (2016) who observed less than 50\% survival in all three clones (Preble, SX61 and Fish Creek). Mosseler et al. (2014a) observed similar clonal prominence of Salix eriocephala which out-survived its closest competitor, S. nigra, by $20 \%$ on crushed shale overburden in New Brunswick, Canada. Rooting ability of different clones was cited as the main reason for survival differences on mine soils with species native to riparian environments demonstrating the greatest rooting ability (and survival) (Kuzovkina and Volk, 2009). Riparian willow varieties have shown tolerance for deposition by their ability to propagate additional roots when stools become buried, as well as adaptability to root exposure and soil erosion. Each of the clones in this study were riparian varieties, but Preble and SX61 proved superior for the rocky, sandstone-derived mine soil. The prominence of the two clones enabled us to dismiss Fish Creek as a useful clone for reclamation in the Appalachian region and recommend clones with Salix viminalis, $S$. sachalinensis and S. miyabeana lineage as the focuses of future SRWC research for mine reclamation.

The effects of fertilizer on survival were less direct and were confounded by clonal performance. Fertilization was not a main determinant of survival, consistent with other findings (Stolarski et al., 2015; Kopp et al., 1996). For this study, both fertilizer types reduced survival of Fish Creek, possibly due to over-fertilization after the initial reclamation amendments at the site or due to the inherently poor adaptation to the minesoils displayed by the clone. By contrast, for the Preble and SX61 clones, both fertilizer treatments increased survival rates over the two-year 
period. On those grounds, we recommend fertilization in the establishment year as a viable method to enhance survival in willow clones that are suitable to sandstone-derived minesoil.

\section{Growth}

Analyses showed that the genotypic effects of clone were the predominant influence on willow growth. In measures of total plant height, total basal area, biomass accrual and leaf to shoot ratio, clone was the only significant treatment effect. For maximum stem diameter, clone had the most significant effect, with some influence of planting position and fertilizer treatment. These results were consistent with the strong genotypic effect observed by Bouman and Sylliboy (2012) in the biomass productivity and allocation of twelve willow clones grown on abandoned, well-drained agricultural soils near Sydney, Cape Breton, Australia. The measures in this study have provided means to compare growth and biomass among the clones deployed at Mt. Storm, and compare growth and yield of this willow plantation to previous studies.

Preble emerged as the superior clone on the minesoil at Mt. Storm. It exceeded the other two clones in height, diameter, basal area and biomass production. Preble was likely superior because it is a triploid hybrid of Salix viminalis x S. miyabeana. Such willow clones have shown promise as superior performers across ten sites in New York, Connecticut, Vermont and Michigan in the United States and in Saskatchewan and Ontario, Canada (Fabio et al., 2017). In the most recent research, "Fabius", a triploid hybrid of S. viminalis and S. miyabeana, similar to Preble, out-yielded SX61 by 1.8 $\mathrm{Mg} \mathrm{ha}^{-1} \mathrm{yr}^{-1}$ on average (Fabio et al., 2017). Additional evidence of the superiority of triploid clones was indicated by Serapiglia et al. (2014) whose trials compared 75 tetraploid, triploid, and diploid genotypes on a silt loam soil at the Cornell University Agricultural Experiment Station in Geneva, NY. Triploid genotypes rendered the majority of yields in the upper $50^{\text {th }}$ percentile of the study. 
At Mt. Storm, the Preble and SX61 clones performed consistently with the literature in relation to each other. Across six proving trials at agricultural sites in New York, Vermont, Michigan, and Illinois, Preble yielded 18\% greater biomass than SX61 (Gouker et al., 2015). In this study, Preble accrued 3 times the biomass of SX61 and 8.5 times the biomass of Fish Creek. Fish Creek has also been cited as a poor performer by Serapiglia et al. (2014) who noted significant stem dieback that reduced biomass yields. Fish Creek may have performed so poorly because of site sensitivity. Serapiglia et al. (2013) found Fish Creek performance was less on soil with a pH of 5.0 compared a soil with $\mathrm{pH}$ of 6.5 whereas SX61 produced consistent yields across sites. Sensitivity to the acidic minesoils may explain the comparatively poor performance of the Fish Creek.

With respect to aboveground carbon allocation and growth efficiencies, measurements of leaf to shoot ratios did not produce a clear, most efficient clone. In theory, the clone with the smallest leaf to shoot ratio was the most efficient, which in this case was Fish Creek. Results from Bouman and Sylliboy (2012) suggested that Fish Creek was highly efficient in aboveground growth based on chlorophyll to shoot mass ratio compared to 12 clones including SX61. But the high mortality and poor vigor of Fish Creek in this study negated the implications of its allocation patterns. Preble and SX61 grew at approximately the same aboveground biomass allocation efficiency, $0.4 \mathrm{~g} \mathrm{~g}^{-1}$, under the prevailing conditions of poor moisture and nutrient availability in the minesoil.

It did appear that horizontally planted cuttings, produced slightly larger diameter shoots. This result added to conflicting results by previous experimenters. Lowthe-Thomas et al. (2010) also found that diameters of stems from "layflat" planted cuttings were slightly greater than vertically planted for willow grown on a permeable stony clay loam at Builth, Wales. However, 
Larsen et al. (2014) found that stem diameters of vertically planted cuttings were $5 \mathrm{~mm}$ greater than horizontally planted cuttings in loamy sand soil that was previously cropped with grain in Jutland, Denmark. The conclusion of this study was that horizontally planted stems were at a survival disadvantage on the mine soil and therefore did not successfully produce biomass.

Clone advantage of Preble was still dominant across all fertilizer treatments. Further support for the dominance of clone effects on stem diameter emerged when measurements were summarized as total basal areas. The basal area of Preble stems was twice those of SX61. Agglomerated measures of stem diameter may be a more valuable growth metric than measures of maximum stem diameter based on correlation to biomass production. Mosseler et al. (2014a) found the average of multiple stem diameters more closely related to biomass measurements than a single measurement of maximum stem diameter.

Fertilizer only had significant effects on stem diameter, and was not a significant factor for biomass production at Mt. Storm. Effectiveness of fertilizers has previously varied among sites based on soil properties and moisture. Only three of twenty-two studies reviewed by Stoof et al. (2015) reported statistically significant increase in willow yields as a result of fertilizer application. However, Keoleian and Volk (2005) recommended fertilization of SRWC plantations triennially in order to replenish nutrients lost through harvesting based on their review of willow cultivation research up to 2005. At Mt. Storm, the rocky, coarse-grained soil worked against fertilizer effectiveness. With minesoil containing less than $10 \%$ silt and clay particles, nutrient ions did not have clay particles and organic particles to adsorb them. Ions were likely subject to leaching below the zone of uptake for the young root systems, or were transported from the plantation site by overland flow. 
Compared to plantations in agricultural soils, willow heights on the minesoil were small. The tallest treatment combination with Preble stems produced heights of $65 \mathrm{~cm}$ after two growing seasons. Stolarski et al. (2008) recorded Salix viminalis heights ranging between 224 and $252 \mathrm{~cm}$ for willow with an annual cutting cycle on heavy loam and silty clay soils in Poland. As Preble is a $S$. viminalis hybrid, two-year growth was expected to exceed $2 \mathrm{~m}$ consistently on agricultural sites. Mosseler et al. (2014a) offered results from their study on mines in Salmon Harbour, New Brunswick that corroborate the results from Mt. Storm. Their willow heights on minesoils ranged from 50 to $150 \mathrm{~cm}$.

As heights were stunted, so were diameters. Maximum stem diameters at Mt. Storm were 10 to $12 \mathrm{~mm}$ for the Preble clone. Mosseler et al. (2014a) obtained similar results on minesoils in New Brunswick with maximum stem diameters between 5 and $15 \mathrm{~mm}$. Conversely, their agricultural trials rendered plants with maximum stem diameter between 10 and $75 \mathrm{~mm}$. Rönnberg-Wästljung (2001) found maximum diameters between 22.4 and $24.0 \mathrm{~mm}$ in two-year growth of S. viminalis on sandy agricultural soils in Sweden.

\section{Biomass}

The small comparative growth at Mt. Storm translated to small biomass growth. Biomass measured from the Preble clone was $0.17 \mathrm{Mg} \mathrm{ha}^{-1} \mathrm{yr}^{-1}$ which exceeded $0.01 \mathrm{Mg} \mathrm{ha}^{-1} \mathrm{yr}^{-1}$, the biomass measured by Nobert et al. (2016) for the Preble clone on West Virginia surface mines. But these were dwarfed by other studies as Fabio et al. (2017) reported approximately $7 \mathrm{Mg} \mathrm{ha}^{-1}$ $\mathrm{yr}^{-1}$ each from the Fish Creek and SX61 clones and approximately $8 \mathrm{Mg} \mathrm{ha}^{-1} \mathrm{yr}^{-1}$ from triploid hybrids similar to Preble. Typical yields from commercial biomass plantations in the United States have totaled $10 \mathrm{Mg} \mathrm{ha}^{-1} \mathrm{yr}^{-1}$ (Keoleian and Volk, 2005). Total yields from surface mine trials in West Virginia were far lower. The average yield of the Mt. Storm plantation was 0.08 
$\mathrm{Mg} \mathrm{ha}^{-1} \mathrm{yr}^{-1}$. Projected yield from Nobert et al., 2016 was similarly poor at $0.03 \mathrm{Mg} \mathrm{ha}^{-1} \mathrm{yr}^{-1}$ across all treatments. However, the willow yield at Mt. Storm was not drastically different than yields reported by Zipper et al. (2011c) for hybrid poplar (Populus spp.) and sycamore (Platanus spp.) on ripped minesoils in Wise County Virginia, $0.3 \mathrm{Mg} \mathrm{ha}^{-1} \mathrm{yr}^{-1}$ and $0.4 \mathrm{Mg} \mathrm{ha}^{-1} \mathrm{yr}^{-1}$, respectively. Clearly, surface mines have not yet produced near the biomass yields of agricultural sites. Even marginal agricultural sites like those in Fabio et al. (2017) produced willow yields from 2 to $13 \mathrm{Mg} \mathrm{ha}^{-1} \mathrm{yr}^{-1}$. Further improvements in SRWC production of willow or treatments to overcome site conditions will be required before widespread deployment on surface mines in West Virginia.

Of more immediate promise were the yields achieved in trials of the perennial grasses, switchgrass (Panicum virgatum) and miscanthus (Miscanthus giganteus), on reclaimed Appalachian mines. The highest willow yielded 3.2 $\mathrm{Mg} \mathrm{ha}^{-1} \mathrm{yr}^{-1}$ less than switchgrass on and 4.2 $\mathrm{Mg} \mathrm{ha}^{-1} \mathrm{yr}^{-1}$ less than miscanthus grown on $15 \mathrm{~cm}$ of topsoil over mixed sandstone and shale overburden in Upshur County, West Virginia (Scagline et al., 2015). The woody crop of greatest potential appeared to be black locust (Robinia pseudoacacia) which yielded $2 \mathrm{Mg} \mathrm{ha}^{-1} \mathrm{yr}^{-1}$ in the trial by Zipper et al. (2011c). Grasses grow readily on marginal lands of low fertility (Scagline et al., 2015). Woody crops may require more time to become established to peak MAI and reach comparable yields.

\section{Reclamation}

In terms of economic returns for mine operators, willow production on reclaimed land has not yet achieved viable yields. Furthermore, a robust biomass economy with a network of biomass-firing power plants has not been established to date. Conceivably, such institutions will need to first be assured a constant supply of fuel-stock in order to develop. What willow can do 
at this point, is advance reclamation toward revegetation bond release with the intent to harvest for bio-energy in the future. The West Virginia reclamation code was expressly revised in 2011 to allow for bio-energy plantations to fulfill the requirements for bond release (WVDEP, 2011). Willow did survive on the minesoil, but may require time, beyond one 3-year SRWC cutting cycle to reap the benefits. At this point, willow plantations can offer a means to establish an early-successional plant community for minesoil improvement as a catalyst to achieving high yields of SRWC or timber production. Over time, willow can improve soil density and contribute to nutrient cycling via litterfall (Kuzovkina and Quigley, 2005). To that effect, Wade et al. (1985) have demonstrated soil improvements including $\mathrm{pH}$ increase and reduction in soluble salt levels over 18 years on minesoils revegetated with twenty-five tree species and twenty-five shrub species. Successive years of willow measurement and minesoil characterization will be necessary to determine if willow biomass improves over time and if willow do improve minesoil properties.

\section{CONCLUSION}

Minesoil conditions (high acidity, coarse and rocky texture, high bulk density, limited nutrient availability) negatively affected willow survival and growth in comparison to studies of agricultural SRWC plantations. The experimental, horizontal planting treatment was disproved as a viable method to ease planting in rocky, dense minesoils because of significantly high mortality among horizontally planted cuttings. Fertilizers produced negligible effects in this study on survival and growth. However, as new minesoils are typically low in available nutrients, it is recommended to continue following established SRWC willow practices of fertilization with $100 \mathrm{~kg} \mathrm{~N} \mathrm{ha}^{-1}$ at willow establishment. If this level of fertilization was applied during reclamation, additional fertilizers should not be applied as applications above $100 \mathrm{~kg} \mathrm{~N}$ 
ha $^{-1}$ have proven ineffective (Sevel et al., 2013). Additionally, excessive fertilizer application may impart damage to willow growing in stressed, minesoil conditions. The importance of clone selection was demonstrated for minesoil applications. This study indicated some strength of a triploid hybrid clone (Preble) under minesoil conditions, which is similar to other studies and consistent with the purpose of such clones, to succeed on a wide range of marginal sites (Fabio et al., 2017). The SX61 clone remained a good performing natural willow accession that appeared suitable for reclamation based on survival, whereas the Fish Creek clone did not show suitability for future mine trials. Biomass production did suffer due to minesoil conditions but it must be considered that new minesoils are being developed from parent rock. Yields at the same levels as agricultural soils were not expected initially but are anticipated to improve in subsequent years as minesoils develop structure and nutrient cycling occurs. As the results of this study imply, SRWC of shrub willow, as a reclamation method will not provide immediate economic return beyond reclamation bond release. However, the potential exists for economically viable yields as soils improve. Trials beyond the two-year length of this study will be necessary to determine an appropriate timeframe for expected return-on-investment from SRWC willow plantations West Virginia's surface mines.

\section{Acknowledgements}

Arch Coal, Inc.; West Virginia Division of Energy; The Appalachian Hardwood Center at West Virginia University: John Howell, Jeff Slahor, Larry Osborn; Graduate Assistants: Adele Fenwick, Kevin Tomlinson, Henry Liebermann, Alex Storm, Aaron Lutz; College Staff: Ida Holaskova 


\section{REFERENCES}

Abrahamson LP, Robison DJ, Volk TA, White EH, Neuhauser EF, Benjamin WH, Peterson JM. 1997. Sustainability and environmental issues associated with willow bioenergy development in New York (U.S.A.). Biomass and Bioenergy 15(1):17-22.

Abrahamson LP, Volk TA, Kopp RF, White E H, Ballard JL. 2010. Willow biomass producer's handbook (revised) [Internet]. Syracuse (NY): SUNY-ESF Short Rotation Woody Crops Program; [cited 2016 Nov 22]. Available from http://www.esf.edu/willow/documents/ProducersHandbook.pdf

Adegbidi HG, Briggs RD, Volk TA, White EH, Abrahamson LP. 2003. Effect of organic amendments and slow-release nitrogen fertilizer on willow biomass production and soil chemical characteristics. Biomass and Bioenergy 25(4):389-98.

AgACIS. Applied Climate Information System [Internet]. 2016. Regional Climate Centers; [cited 2017 Mar 16]. Available from http://agacis.rcc-acis.org/

Albertsson J, Hansson D, Bertholdsson N, Åhman I. 2014. Site-related set-back by weeds on the establishment of 12 biomass willow clones. Weed Research 54(4):398-407.

Andrews JA, Burger JA, Kelting DL, Johnson JE, Torbert JL. 1998. Minesoil and site properties associated with early height growth of eastern white pine. Journal of Environmental Quality 27(1):192-9.

Angel PN, Barton CD, Warner RC, Agouridis C, Taylor T, Hall SL. 2008. Forest establishment and water quality characteristics as influenced by spoil type on a loose graded surface mine in eastern Kentucky. In: Barnhisel RI, editor. American Society of mining and Reclamation. ASMR 2008 - Twenty-fifth Annual Meeting; 2008 June 14-19; Richmond, VA. Lexington (KY): American Society of Mining and Reclamation. p 28-65.

Aronsson P, Rosenqvist H. 2011. Gödslingsrekommendationer för Salix 2011 [Fertilizer recommendations for Salix 2011]. SLU, Institut för Växtproduktionsekologi. [Insititute for Crop Production Ecology]. Rapport 23 marts 2011. [Report 23 March 2011]. [in Swedish].

ASTM International. 2009. ASTM D6913-04(2009)e1 Standard Test Methods for Particle-Size Distribution (Gradation) of Soils Using Sieve Analysis [Internet]. West Conshohocken (PA): ASTM International; [cited 2017 Mar 22] Available from https://doi.org/10.1520/D6913-04R09E01

Bouman OT, Sylliboy J. 2012. Biomass allocation and photosynthetic capacity of willow (Salix spp.) bio-energy varieties. Forstarch Forstarchiv 83(4):139-43.

Burger JA, Mitchem D, Scott D. 2002. Field assessment of mine site quality for establishing hardwoods in the Appalachians. In: Barnhisel RI, editor. American Society of Mining and Reclamation. ASMR 2002 - Nineteenth Annual Meeting; 2002 June 9-13; Lexington, KY. Lexington (KY): American Society of Mining and Reclamation. p 226-240. 
Burger J, Graves D, Angel P, Davis V, Zipper C. 2005. Forest Reclamation Advisory No. 2 - The forestry reclamation approach [Internet]. Pittsburgh (PA): U.S. Office of Surface Mining, Appalachian Regional Reforestation Initiative; [cited 2016 Nov 22]. Available from http://arri.osmre.gov/Publications/Publications.shtm\#FRAs

Burger J, Davis V, Franklin J, Zipper C, Skousen J, Barton C, Angel P. 2009. Forest Reclamation Advisory No. 6 - Tree-compatible ground covers for reforestation and erosion control [Internet]. Pittsburgh (PA): U.S. Office of Surface Mining, Appalachian Regional Reforestation Initiative; [cited 2016 Nov 22]. Available from: http://arri.osmre.gov/Publications/Publications.shtm\#FRAs.

Cameron K, Smart L, Volk T, Abrahamson L. 2007. Salix sachalinensis 'SX61' Fact sheet [Internet]. Syracuse (NY): The Research Foundation of State University of New York; [cited 2016 Nov 22]. Available from http://digitalcommons.esf.edu/cgi/viewcontent.cgi?article=1007\&context=wpmoutreach

Cao Y, Lehto T, Repo T, Silvennoinen R, Pelkonen P. 2011. Effects of planting orientation and density of willows on biomass production and nutrient leaching. New Forests: International Journal on the Biology, Biotechnology, and Management of Afforestation and Reforestation 41(3):361-77.

Casselman CN, Fox TR, Burger JA, Jones AT, Galbraith JM. 2006. Effects of silvicultural treatments on survival and growth of trees planted on reclaimed mine lands in the Appalachians. Forest Ecology and Management 223(1-3):403-14.

Cherubini F. 2010. The biorefinery concept: Using biomass instead of oil for producing energy and chemicals. Energy Conversion and Management 51(7):1412-21.

Daniels LW and Haering KC. 2006. Concepts of basic soil science. In: Haering KC and Evanylo GK, editors. The mid-Atlantic nutrient management handbook. Mid-Atlantic regional water program. p. 31-52.

Davis V, Franklin J, Zipper C, Angel P. 2010. Forest Reclamation Advisory No. 7 - Planting hardwood tree seedlings on reclaimed mine land in Appalachia [Internet]. Pittsburgh (PA): U.S. Office of Surface Mining, Appalachian Regional Reforestation Initiative; [cited 2016 Nov 22]. Available from http://arri.osmre.gov/Publications/Publications.shtm\#FRAs.

DeLong C, Skousen J, Pena-Yewtukhiw E. 2012. Bulk density of rocky mine soils in forestry reclamation. Soil Science Society of America Journal 76(5):1810-5.

Edelfeldt S, Lundkvist A, Forkman J, Verwijst T. 2015. Effects of cutting length, orientation and planting depth on early willow shoot establishment. BioEnergy Research 8(2):796-806.

Emerson P, Ziemkiewicz P, Skousen J. 2009. Survival and growth of hardwoods in brown versus gray sandstone on a surface mine in West Virginia [electronic resource]. Journal of Environmental Quality 38(5):1821-9. 
Ericsson T. 1994. Environmental aspects of energy forest cultivation nutrient cycling in energy forest plantations. Biomass \& Bioenergy 6(1):115-21.

Ericsson T, Rytter L, Vapaavuori E. 1996. Physiology of carbon allocation in trees. Biomass and Bioenergy 11(2):115-127.

Fabio ES, Volk TA, Miller RO, Serapiglia MJ, Gauch HG, Van Rees KCJ, Hangs RD, Amichev BY, Kuzovkina YA, Labrecque M, Johnson GA, Ewy RG, Kling GJ, Smart LB. 2017. Genotype $\times$ environment interaction analysis of North American shrub willow yield trials confirms superior performance of triploid hybrids. GCB Bioenergy 9(2):445-59.

Fjell I. 1985. Preformation of root primordia in shoot and root morphogenesis in Salix viminalis. Nordic Journal of Botany 5:357-376.

Gorman J, Skousen J, Sencindiver J, Ziemkiewicz P. 2001. Forest productivity and minesoil development under a white pine plantation versus natural vegetation after 30 years. In: Barnhisel RI, editor. American Society of mining and Reclamation. ASMR 2001 Eighteenth Annual Meeting; 2001 June 3-7; Albuquerque, NM. Lexington (KY): American Society of Mining and Reclamation. p 103-111.

Gouker F, Fabio E, Smart L. 2015. 'Preble' Salix viminalis x S. miyabeana Fact Sheet [Internet]. Ithaca (NY): Cornell University College of Agriculture and Life Sciences; [cited 2016 Nov 22]. Available from https://willow.cals.cornell.edu/files/2015/05/Preble-new2015_10_18_v9-yxivw5.pdf

Johnson CD, Skousen JG. 1995. Minesoil properties of 15 abandoned mine land sites in West Virginia. Journal of Environmental Quality 24:635-643.

Keoleian GA, Volk TA. 2005. Renewable energy from willow biomass crops: Life cycle energy, environmental and economic performance. Critical Reviews in Plant Sciences 24(5):385406.

King J, Skousen J. 2003. Tree survival on a mountaintop surface mine in West Virginia. In: Barnhisel RI, editor. American Society of mining and Reclamation. ASMR 2003 Twentieth Annual Meeting; 2003 June 3-6; Billings, MT. Lexington (KY): American Society of Mining and Reclamation. p 563-574.

Kopp RF, Abrahamson LP, White EH, Nowak CA, Zsuffa L, Burns KF. 1996. Woodgrass spacing and fertilization effects on wood biomass production by a willow clone. Biomass and Bioenergy 11(6):451-7.

Kopp RF, Smart LB, Maynard CA, Isebrands JG, Tuskan GA, Abrahamson LP. 2001. The development of improved willow clones for eastern North America. Forestry Chronicle 77:287-292.

Kuzovkina YA, Knee M, Quigley MF. 2004. Soil compaction and flooding effects on the growth of twelve Salix L. species. Journal of Environmental Horticulture 22:155-160. 
Kuzovkina YA, Quigley MF 2005. Willows beyond wetlands: Uses of Salix L. species for environmental projects. Water Air Soil Poll. 162, 183-204

Kuzovkina YA, Volk TA. 2009. The characterization of willow (Salix L.) varieties for use in ecological engineering applications: co-ordination of structure, function and autecology. Ecological Engineering 35, 1178-1189.Larsen SU, Jørgensen U, Kjeldsen JB, Lærke PE. 2014. Long-term yield effects of establishment method and weed control in willow for short rotation coppice (SRC). Biomass and Bioenergy 71:266-74.

Ledin S. 1996. Willow wood properties, production and economy. Biomass and Bioenergy 11(23):75-83.

Lowthe-Thomas S, Slater FM, Randerson PF. 2010. Reducing the establishment costs of short rotation willow coppice (SRC) - A trial of a novel layflat planting system at an upland site in mid-wales. Biomass \& Bioenergy 34(5):677-86.

Maxwell A, Grushecky S, Strager M. 2012. Biomass development on surface mine sites in West Virginia: Acreage potential. Forestry Reclamation Approach.

McCracken AR, Moore JP, Walsh LRE, Lynch M. 2010. Effect of planting vertical/horizontal willow (Salix spp.) cuttings on establishment and yield. Biomass and Bioenergy 34(12):1764-9.

Mosseler A, Major JE, Labrecque M. 2014a. Growth and survival of seven native willow species on highly disturbed coal mine sites in eastern Canada. Canadian Journal of Forest Research 44(4):340-9.

Mosseler A, Major JE, Labrecque M, Larocque GR. 2014b. Allometric relationships in coppice biomass production for two North American willows (Salix spp.) across three different sites. Forest Ecology and Management 320:190-6.

Nobert HA, McGill DW, Grushecky ST, Skousen JG, Schuler JL. 2016. Salix spp. As a biomass crop: investigating its potential on mined lands and the use of biochar as a soil amendment. Journal American Society of Mining and Reclamation 5(2):58-76.

Page-Dumroese DS, Brown RE, Jurgensen MF, Mroz GD. 1999. Comparison of Methods for Determining Bulk Densities of Rocky Forest Soils. Soil Science Society of America Journal 63:379-383.

Poorter H, Niklas KJ, Reich PB, Oleksyn J, Poot P, Mommer L. Biomass allocation to leaves, stems and roots: meta-analysis of interspecific variation and environmental control. 2012. New Phytologist 193:30-50.

Potter HS, Weitzman S, Trimble GR. 1951. Reforestation of strip mined lands in West Virginia. USDA Forest Service Northeastern Forest Experiment Station. Station paper No. 43. 
Rodrigue JA, Burger JA. 2004. Forest soil productivity of mined land in the midwestern and eastern coalfield regions. Soil Science Society of America Journal 68(3):833-44.

Rönnberg-Wästljung AC. 2001. Genetic structure of growth and phenological traits in Salix viminalis. Canadian Journal of Forest Resources 31(2):276-82.

Scagline S, Skousen J, Griggs T. 2015. Switchgrass and miscanthus yields on reclaimed surface mines for bioenergy production. Journal American Society of Mining and Reclamation 4(2):80-90.

Sevel L, Nord-Larsen T, Ingerslev M, Jørgensen U, Raulund-Rasmussen K. 2014. Fertilization of SRC willow, I: Biomass production response. Bioenergy Research 7(1):319-28.

Serapiglia MJ, Cameron KD, Stipanovic AJ, Abrahamson LP, Volk TA, Smart LB. 2013. Yield and woody biomass traits of novel shrub willow hybrids at two contrasting sites. BioEnergy Research 6(2):533-46.

Serapiglia MJ, Gouker FE, Smart LB. 2014. Early selection of novel triploid hybrids of shrub willow with improved biomass relative to diploids. BMC Plant Biology 14:74.

Skousen J, Zipper C, Burger J, Angel P, Barton C. 2011. Selecting topsoil substitutes for forestry mine soils. In: Barnhisel RI, editor. American Society of mining and Reclamation. ASMR 2011 - Twenty-eighth Annual Meeting; 2011 June 11-16; Bismarck, ND. Lexington (KY): American Society of Mining and Reclamation. p 591-609.

Skousen J, Zipper CE. 2014. Post-mining policies and practices in the eastern USA coal region. International Journal of Coal Science \& Technology 1(2):135-51.

Skvortsov, A.K., 1999. Willows of Russia and adjacent countries: taxonomical and geographical review. University of Joensuu, Faculty of Mathematics and Natural Science Report Series 39.

Smart LB, Volk TA, Lin J, Kopp RF, Phillips IS, Cameron KD, White EH, Abrahamson LP. 2005. Genetic improvement of shrub willow (Salix spp.) crops for bioenergy and environmental applications in the United States. Unasylva 56:51-55.

Smart LB, Cameron KD. 2008. Genetic improvement of willow (Salix spp.) as a dedicated bioenergy crop. In: Vermerris W, editor. Genetic improvement of bioenergy crops. New York (NY): Springer New York. 377 p.

Smart LB, Cameron KD, Volk TA, Abrahamson LP. 2008. Breeding, selection, and testing of shrub willow as a dedicated energy crop. In: NABC Report 19 Agricultural Biofuels: Technology, Sustainability, and Profitability. Ithaca (NY): National Agricultural Biotechnology Council p. 85-92. 
Stolarski M, Szczukowski S, Tworkowski J, Klasa A. Productivity of seven clones of willow coppice in annual and quadrennial cutting cycles. 2008. Biomass and Bioenergy 23:12271234.

Stolarski MJ, Krzyzaniak M, Szczukowski S, Tworkowski J, Bieniek A. 2014. Short rotation woody crops grown on marginal soil for biomass energy. Polish Journal of Environmental Studies 23(5):1727-39.

Stolarski MJ, Rosenqvist H, Krzyżaniak M, Szczukowski S, Tworkowski J, Gołaszewski J, Olba-Zięty E. 2015. Economic comparison of growing different willow cultivars. Biomass Bioenergy 81:210-5.

Stoof CR, Richards BK, Woodbury PB, Fabio ES, Brumbach AR, Cherney J, Das S, Geohring L, Hansen J, Hornesky J, Mayton H, Mason C, Ruestow G, Smart LB, Volk TA, Steenhuis TS. 2015. Untapped potential: Opportunities and challenges for sustainable bioenergy production from marginal lands in the northeast USA. BioEnergy Research 8(2):482-501.

Sweigard R, Burger J, Zipper C, Skousen J, Barton C, Angel P. 2007. Forest Reclamation Advisory No. 3 - Low compaction grading to enhance reforestation success on coal surface mines [Internet]. Pittsburgh (PA): U.S. Office of Surface Mining, Appalachian Regional Reforestation Initiative; [cited 2016 Nov 22]. Available from http://arri.osmre.gov/Publications/Publications.shtm\#FRAs.

Thomas C, Sexstone A, Skousen J. 2015. Soil biochemical properties in brown and gray mine soils with and without hydroseeding, Soil, 1, 621-629.

Volk TA, Abrahamson LP, Nowak CA, Smart LB, Tharakan PJ, White EH. 2006. The development of short-rotation willow in the northeastern united states for bioenergy and bioproducts, agroforestry and phytoremediation. Biomass and Bioenergy 30(8-9):715-27.

Volk TA, Heavey JP, Eisenbies MH. 2016. Advances in shrub-willow crops for bioenergy, renewable products, and environmental benefits. Food and Energy Security 5(2):97-106.

Wade GL, Thompson RL, Vogel WG. 1985. Success of trees and shrubs in an 18-year-old planting on mine spoil. Research Paper NE-567. Broomall (PA): U.S. Department of Agriculture, Forest Service, Northeastern Forest Experiment Station. 10 p.

Weih M. 2001. Evidence for increased sensitivity to nutrient and water stress in a fast-growing hybrid willow compared with a natural willow clone. Tree Physiology 21(15):1141-8.

Weih M, Bonosi L, Ghelardini L, Rönnberg-Wästljung AC. 2011. Optimizing nitrogen economy under drought: Increased leaf nitrogen is an acclimation to water stress in willow (Salix spp.). Annals of Botany 108(7):1347-53. 
West Virginia Department of Environmental Protection (WVDEP). 2011. West Virginia Coal Surface Mining Reclamation Rule (38 CSR 2). Available from:

http://www.dep.wv.gov/dmr/codes/Pages/default.aspx. Accessed 7 February 2017.

Willebrand E, Ledin S, Verwijst T. 1993. Willow coppice systems in short rotation forestry: Effects of plant spacing, rotation length and clonal composition on biomass production. Biomass and Bioenergy 4(5):323-31.

Willowpedia: a willow energy crop information resource at Cornell University [Internet]. Ithaca (NY): Cornell University College of Agriculture \& Life Sciences; [cited 2017 February 7]. Available from: http://willow.cals.cornell.edu//.

Zipper CE, Burger JA, McGrath JM, Rodrigue JA, Holtzman GI. 2011a. Forest restoration potentials of coal-mined lands in the eastern United States. Journal of Environmental Quality 40(5):1567-77.

Zipper CE, Burger JA, Skousen JG, Angel PN, Barton CD, Davis V, Franklin JA. 2011 b. Restoring forests and associated ecosystem services on Appalachian coal surface mines. Environmental Management 47(5):751-65.

Zipper CE, Evans DM, Burger JA, Fields-Johnson CW, Brunner A, Stanton B. 2011c. Woody biomass production on post-smcra mined lands over three years and comparisons with other studies. In: Barnhisel RI, editor. American Society of mining and Reclamation. ASMR 2011 - Twenty-eighth Annual Meeting; 2011 June 11-16; Bismarck, ND. Lexington (KY): American Society of Mining and Reclamation. p 768-786. 